\title{
Improved modelling of atmospheric ammonia over Denmark using the coupled modelling system DAMOS
}

\author{
C. Geels ${ }^{1}$, H. V. Andersen ${ }^{1, *}$, C. Ambelas Skjøth ${ }^{1,2}$, J. H. Christensen ${ }^{1}$, T. Ellermann ${ }^{1}$, P. Løfstrøm ${ }^{1}$, S. Gyldenkærne ${ }^{1}$, \\ J. Brandt ${ }^{1}$, K. M. Hansen ${ }^{1}$, L. M. Frohn ${ }^{1}$, and O. Hertel ${ }^{1,3}$ \\ ${ }^{1}$ Department of Environmental Science, Aarhus University, Roskilde, Denmark \\ ${ }^{2}$ Department of Physical Geography and Ecosystems Science, Faculty of Science, Lund University, Lund, Sweden \\ ${ }^{3}$ Department for Environmental, Social and Spatial Change, Roskilde University, Denmark \\ * now at: Danish Building Research Institute, Aalborg University, Hørsholm, Denmark
}

Correspondence to: C. Geels (cag@dmu.dk)

Received: 24 January 2012 - Published in Biogeosciences Discuss.: 7 February 2012

Revised: 4 June 2012 - Accepted: 5 June 2012 - Published: 17 July 2012

\begin{abstract}
A local-scale Gaussian dispersion-deposition model (OML-DEP) has been coupled to a regional chemistry-transport model (DEHM with a resolution of approximately $6 \mathrm{~km} \times 6 \mathrm{~km}$ over Denmark) in the Danish Ammonia Modelling System, DAMOS. Thereby, it has been possible to model the distribution of ammonia concentrations and depositions on a spatial resolution down to $400 \mathrm{~m} \times 400 \mathrm{~m}$ for selected areas in Denmark. DAMOS has been validated against measured concentrations from the dense measuring network covering Denmark. Here measured data from 21 sites are included and the validation period covers 2-5 years within the period 2005-2009. A standard time series analysis (using statistic parameters like correlation and bias) shows that the coupled model system captures the measured time series better than the regional- scale model alone. However, our study also shows that about $50 \%$ of the modelled concentration level at a given location originates from non-local emission sources. The local-scale model covers a domain of $16 \mathrm{~km} \times 16 \mathrm{~km}$, and of the locally released ammonia $\left(\mathrm{NH}_{3}\right)$ within this domain, our simulations at five sites show that $14-27 \%$ of the locally (within $16 \mathrm{~km} \times 16 \mathrm{~km}$ ) emitted $\mathrm{NH}_{3}$ also deposits locally. These results underline the importance of including both high-resolution local-scale modelling of $\mathrm{NH}_{3}$ as well as the regional-scale component described by the regional model. The DAMOS system can be used as a tool in environmental management in relation to assessments of total nitrogen load of sensitive nature areas in intense agricultural regions. However, high spatio-temporal resolution in input parameters like $\mathrm{NH}_{3}$ emissions and landuse data is required.
\end{abstract}

\section{Introduction}

The EEA's third European environmental assessment published in 2003 concluded that, despite considerable improvements over the 1990s, critical loads for nitrogen $(\mathrm{N})$ were exceeded for almost $60 \%$ of the European ecosystems (EEA, 2003). In recent years, the agricultural nutrient balance has improved for many of the EU member states, but according to the most recent estimates more than $40 \%$ of sensitive terrestrial and freshwater ecosystem areas in these countries are still subject to atmospheric $\mathrm{N}$ depositions above critical loads (EEA, 2010). In addition, it is well documented that also for many coastal marine ecosystems, the atmospheric depositions play a significant role for the overall $\mathrm{N}$ loads (Spokes et al., 2006; Spokes and Jickells, 2005). Exceedances of critical loads may on the long term lead to loss of biodiversity (Bobbink et al., 2010; Stevens et al., 2004; Stevens et al., 2010), where valuable rare species are in danger of being lost (Krupa, 2003). Critical load exceedances have received increasing scientific and political attention in Europe over the last couple of decades. This awareness calls for new strategies (Sutton et al., 2011) that in a balanced way deal with all major nutrient sources (Conley et al., 2009) and include high quality assessment tools that deal with these sources for management and policy making, both regarding protection of coastal areas (Bartnicki et al., 2011; Geels et al., 2012; Hertel et al., 2003; Langner et al., 2009) and of sensitive ecosystems (Sutton et al., 2007).

In the close vicinity of intense agricultural activities, deposition of locally emitted ammonia $\left(\mathrm{NH}_{3}\right)$ may totally dominate the $\mathrm{N}$ loads to the terrestrial ecosystems (Ferm, 1998). In 
such an area, the annual atmospheric deposition of $\mathrm{N}$ within the first few hundred meters down-wind in the dominating wind direction may be up to $50-80 \mathrm{~kg} \mathrm{~N} \mathrm{ha}^{-1} \mathrm{yr}^{-1}$, depending on the local dispersion conditions, the distance to the source, and the size of the emission (Fowler et al., 1998; Pitcairn et al., 2002). Such high loads are far beyond critical loads for sensitive terrestrial ecosystems, which for many systems are in the range of 10 to $20 \mathrm{~kg} \mathrm{Nha}^{-1} \mathrm{yr}^{-1}$ (UNECE, 2004). The deposition footprint from local $\mathrm{NH}_{3}$ emissions may vary significantly and has been investigated by a range of methods. Indirect estimates using mass balance, ${ }^{15} \mathrm{~N}$ labelling, $\mathrm{SF}_{6}$ to $\mathrm{NH}_{3}$ ratio methods, as well as modelling studies, have thus been applied to determine the fraction of emitted $\mathrm{NH}_{3}$, which is recaptured within the first $2 \mathrm{~km}$ downwind from the source. The results vary widely showing recapture fractions within the first $2 \mathrm{~km}$ downwind from the source between $2 \%$ and up to $60 \%$, but in most cases in the range between $10 \%$ and $40 \%$ (Asman, 1998; Dragosits et al., 2002; Loubet et al., 2001; Loubet et al., 2009; Schou et al., 2006; Sommer and Jensen, 1991). The wide range in recapture fractions reflects the variability in deposition velocities to different surface types, the variability in meteorological conditions, but also the uncertainties in the determination of various parameters and governing processes. One important issue that has attracted much attention in recent years is the bi-directional flux of $\mathrm{NH}_{3}$ that can occur in regions where high atmospheric $\mathrm{NH}_{3}$ levels have saturated the surface (Nemitz et al., 2004; Sutton et al., 2007). Progress has been made towards a better understanding and description of this process, but so far the deposition schemes commonly applied for $\mathrm{NH}_{3}$ do not take this bi-directional flux into account (Flechard et al., 2011; Massad et al., 2010)

Studies in the past have shown that coarse resolution in deposition mapping combined with critical load limits leads to underestimation of the exceedances of critical loads (Spranger et al., 2001). A recent model study concludes on the other hand that national-scale exceedances of critical loads were not very sensitive to grid resolution of the deposition data. However, greater area exceedances were found when the low grid resolution was applied due to averaging of high deposition hot spots within larger grid cells (Dore et al., 2012). A variety of studies have shown that higher spatial resolution in $\mathrm{NH}_{3}$ emission data leads to significant changes in modelled $\mathrm{N}$ depositions (Duyzer et al., 2001; Pul et al., 2004), and our studies have shown that in addition to the high spatial resolution also high temporal resolution may be crucial for the performance of chemistry-transport models (CTMs) (Skjøth et al., 2004; Skjøth et al., 2011). This is also supported by a review with focus on air quality forecasting, stating that dynamical calculations of $\mathrm{NH}_{3}$ emissions are needed for a better prediction of high particulate matter episodes (Menut and Bessagnet, 2010). The emission pattern of $\mathrm{NH}_{3}$ is generally characterised by a large number of point sources (animal housings and storages) surrounded by area sources (fields to which manure is applied) in the ru- ral areas. The scavenging of $\mathrm{NH}_{3}$ from the atmosphere is a competition between two relatively fast processes: the reactions with acid gases and aerosols leading to aerosol phase ammonium $\left(\mathrm{NH}_{4}^{+}\right)$, and the dry deposition (with typical dry deposition velocities in the order of 0.03 to $5.0 \mathrm{~cm} \mathrm{~s}^{-1}$ depending on surface and meteorological conditions) (Hertel et al., 2006). The bi-directional flux mentioned above can also lead to negative deposition velocities over saturated ecosystems. The rate of chemical conversion has been decreasing in recent years (especially when compared to the situation in the 1980s and 1990s) due to reductions in mainly sulphur emissions (leading to reductions in ambient air levels of sulphuric acid $\left(\mathrm{H}_{2} \mathrm{SO}_{4}\right)$ ) (Fagerli and Aas, 2008). In combination with the heterogeneity of the $\mathrm{NH}_{3}$ emissions, this leads to large gradients in $\mathrm{NH}_{3}$ concentration and deposition pattern; gradients that complicate interpretation of observed $\mathrm{NH}_{3}$ levels as these generally cannot be considered spatially representative (Hertel et al., 2007). For a proper assessment of the impact of $\mathrm{NH}_{3}$, this heterogeneity requires a very dense monitoring network (Erisman et al., 2005), and since this is not feasible (especially on the long run), CTMs are typically applied e.g. in combination with observations making use of integrated monitoring and assessment (Hertel et al., 2007).

Current regional CTMs (typically Eulerian) with a resolution of $50 \mathrm{~km}$ to $10 \mathrm{~km}$ tend to over- or underpredict observed $\mathrm{NH}_{3}$ levels across Europe (Simpson et al., 2011). A few national-scale models (including a few Lagrangian models), with resolutions from $5 \mathrm{~km}$ down to $1 \mathrm{~km}$, have shown better agreement with observations (Dore et al., 2012; Dragosits et al., 2002; Nemitz and Sutton, 2004; Pul et al., 2009a; Theobald et al., 2004). Eulerian models are well suited for describing long-range to regional-scale atmospheric transport, but for the local-scale dispersion on resolution of $1 \mathrm{~km}$ or even higher, the Gaussian approach is useful and commonly applied - an example is the OPS model used in the Netherlands (Van Jaarsveld, 2004). In order to obtain improved model performance from applying high resolution local-scale models, it is required that high quality emission inventories with sufficiently high temporal and spatial resolution are available (Kryza et al., 2011). Denmark is a highly intensive agricultural country, and many sensible ecosystems are closely surrounded by areas used for agricultural purposes. Many natural and semi-natural ecosystems are therefore located as a patchwork within the agricultural landscape. It is our goal to combine high resolution emission inventories with local-scale and regional-scale CTMs in a coupled system, in order to improve the model performance with respect to assessing ambient $\mathrm{NH}_{3}$ levels and resulting depositions to this patchwork of ecosystems. We demonstrate this through a presentation of the Danish Ammonia Modelling System (DAMOS) - a combination of the regional- scale Danish Eulerian Hemispheric Model (DEHM) (Christensen, 1997) and the local-scale Gaussian dispersion-deposition model OML-DEP (Sommer et al., 2009). The DAMOS results are 
compared with observations from Danish rural monitoring stations, where we within the period 2005-2009 have a unique data set with measurements from up to 21 different sites. In the model validation, the differences between the regional-scale model alone and the coupled model system are discussed. Moreover, the impact of local versus non-local emissions at different locations in the country is discussed in relation to implications for environmental management and assessment of emission reduction strategies.

\section{Methodology}

In the subsequent sections, first, the monitoring methods and sites are described. Then the national emission inventory and the applied model setup are explained.

\subsection{Monitoring methods and sites}

Within the framework of the Danish Background Air Quality Monitoring Program, concentrations and depositions of eutrophying and acidifying air pollutants have been monitored in Denmark since 1989. Currently, the concentrations of several nitrogen gases are measured at five of the stations in the Danish monitoring network using the filter pack method (Fig. 1). The stations are located in background areas in order to represent the background levels for the particular areas rather than the direct impact of local sources. The stations Anholt and Keldsnor are characterized as coastal sites in areas with only a few local sources for ammonia. Ulborg, Lindet and Tange are all located within agricultural areas in Jutland/Denmark and are characterized as forests sites (U1borg and Lindet) and an agricultural site (Tange). At the five stations, diurnal sampling is carried out with the Danish filter pack sampler (a slightly modified version of the EMEP filter pack sampler). This has in the past been shown to give a reasonable separation between gaseous ammonia and particulate ammonium $\left(\mathrm{NH}_{4}^{+}\right)$under Danish conditions (Andersen and Hovmand, 1994). In the present paper, the yearly mean concentrations of ammonia determined by the filter pack method at the five locations are presented. Additionally, long-term denuder measurements (weekly to half monthly) of ammonia and ammonium are carried out at Ulborg, Anholt, Keldsnor and Lindet. The denuder is a slightly modified version of the denuder described by Ferm (1979), with oxalic acid coating and a flow rate of $1 \mathrm{~L} \mathrm{~min}^{-1}$.

During the years 2006-2009, ammonia has been measured at several locations in Denmark (Fig. 1) with passive diffusion tube sampler ALPHA (Adapted Low-cost Passive High Absorption). Ammonia is absorbed on a filter impregnated with citric acid. The ALPHA samples have been tested against the denuder method at Danish stations with different ammonia levels (for further details see Andersen et al., 2009; Ellermann et al., 2009, and Tang and Sutton, 2003). The measurements cover different regional levels of back- ground concentrations of ammonia, different types of nitrogen sensitive ecosystems and different years. The measurements are run with a half monthly to monthly temporal resolution, and comparisons to model results are included in the present paper.

Table 1 gives an overview of locations, measuring method and time resolution for the concentrations used in the comparisons of measured and modelled values. The uncertainty of the determination of the concentration of ammonia is assumed to be on the order of up to $20 \%$ (Andersen et al., 2009; Andersen and Hovmand, 1994).

\subsection{Ammonia emissions for Denmark}

A dynamical ammonia emission model based on a detailed national inventory and describing the temporal variation throughout the year has been developed for Denmark (Gyldenkærne et al., 2005; Skjøth et al., 2004). The inventory is based on information from national data bases: the Central Husbandry Register and The General Agricultural Register, which gives the geographical location of each agricultural building including stables, storages and fields throughout the country (Nielsen et al., 2011). A standardised ammonia emission for each live stock farm and associated fields is then estimated based on the information on animal type/number and type of crops. The final inventory includes the total annual ammonia emission coming from

1. point sources (farms, storages etc.) at the exact locations of these in Denmark

2. area sources, i.e. emissions from fields due to grown crops as well as emission due to application of manure and mineral fertilizer.

The area sources are distributed within a $100 \mathrm{~m} \times 100 \mathrm{~m}$ grid covering Denmark (Plejdrup and Gyldenkærne, 2011). Examples of the distribution of $\mathrm{NH}_{3}$ emissions across Denmark and within the area around the Tange site are seen in Fig. 1b. and Fig. 2b. The temporal variability of the $\mathrm{NH}_{3}$ emissions is described by 15 additive functions reflecting different agricultural activities and a 16th function describing the contribution from traffic. The functions describe the temporal variations of the emission by specific parameterisations characterising each activity (see Table 2 and for details see Gyldenkærne et al., 2005). An example of the seasonal variations of the different functions and hence the hourly $\mathrm{NH}_{3}$ emission is shown for 2007 at the Tange site (Fig. 3). The parameterisations are based on knowledge on emission factors and the sensitivity of the emission to temperature, wind and ventilation; a simple crop growth model; information on current agricultural practise etc., and the derived temporal variation in the emissions have been shown to agree with measured ammonia levels in Denmark (Skjøth et al., 2004) as well as reflecting the changes in Danish regulations (Skjøth et al., 2008). Recently, the inventory has been extended to 


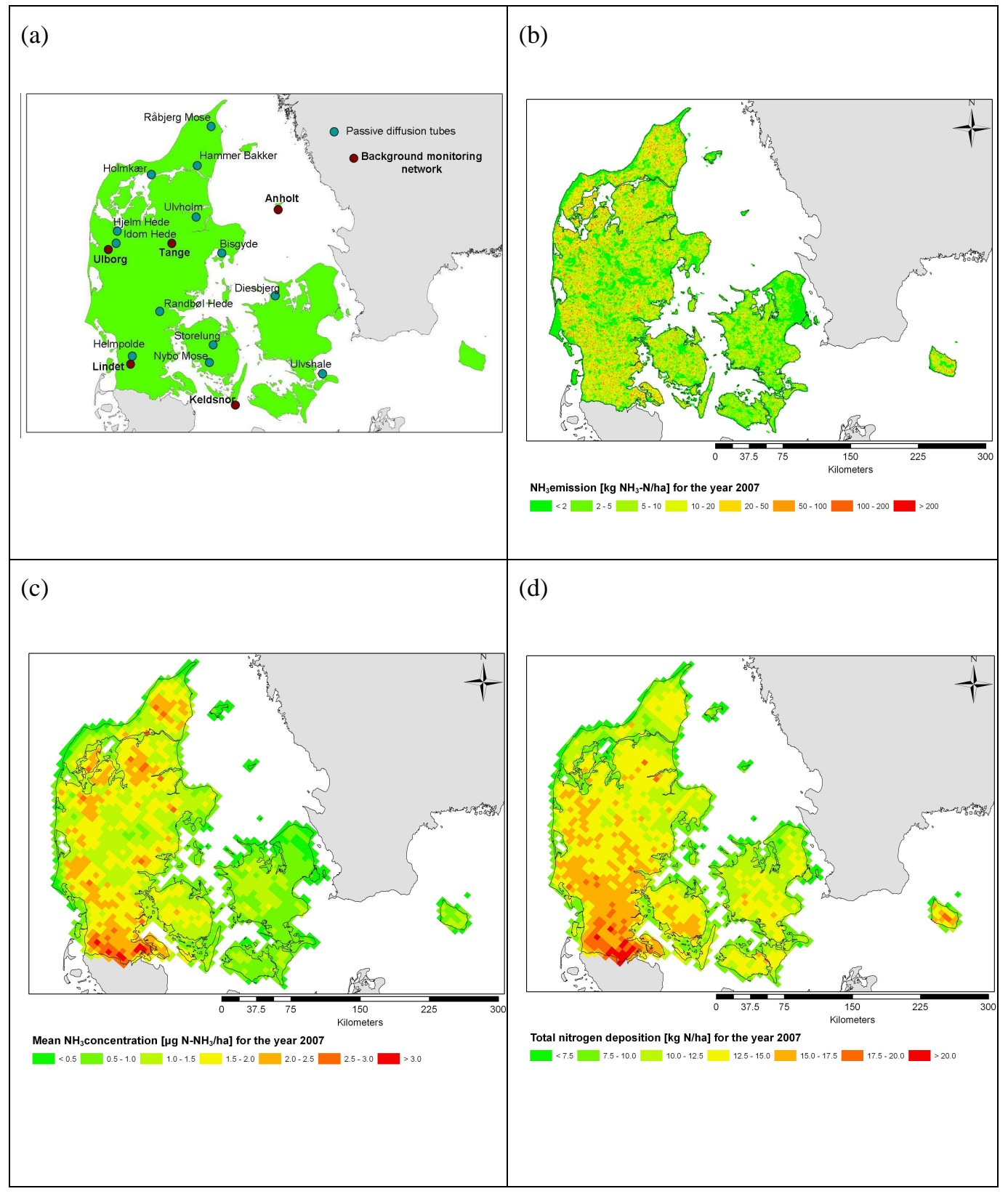

Fig. 1. (a) The locations of the measuring sites included in this study. (b) An example of the distribution of $\mathrm{NH}_{3}$ emissions across Denmark on a $1 \mathrm{~km} \times 1 \mathrm{~km}$ grid for the year 2007. (c) The yearly averaged $\mathrm{NH}_{3}$ concentration over Denmark as calculated by the DEHM model for the year 2007. (d) The yearly total nitrogen load over Denmark as calculated by the DEHM model for the year 2007.

cover Northern Europe, which resulted in improved $\mathrm{NH}_{3}$ calculations at sites in Germany and even led to additional improvements at the Danish sites (Skjøth et al., 2011).

The inventory is updated every year with

1. new data on actual farm size, taking into account the structural development in the agricultural sector,
2. updated nitrogen excretion rates per animal, as these change between years due to increased efficacy (Poulsen et al., 2001; Poulsen, 2011),

3. information on fields allocated to each farm as well as application technique,

4. updated amount of manure available at farm level (farm production minus export and plus export), 
Table 1. Details about the monitoring sites applied in the current study: location, land-use, measuring period and time resolution and measuring method. The geographical positions are shown in Fig. 1a.

\begin{tabular}{lllll}
\hline Station & Land-use & $\begin{array}{l}\text { Measuring } \\
\text { period* }\end{array}$ & Time resolution & $\begin{array}{l}\text { Measuring } \\
\text { method }\end{array}$ \\
\hline Anholt & Grass, coastal & $\begin{array}{l}2005-2009 \\
2007-2009\end{array}$ & $\begin{array}{l}\text { Daily } \\
\text { Half monthly }\end{array}$ & $\begin{array}{l}\text { Filter pack } \\
\text { Denuder }\end{array}$ \\
Keldsnor & Grass, coastal & $2005-2009$ & Daily & Filter pack \\
& & $2005-2009$ & Half monthly & Denuder \\
Lindet & Forest & $2005-2009$ & Daily & Filter pack \\
& & $2005-2009$ & Weekly & Denuder \\
Tange & Grass & $2005-2009$ & Daily & Filter pack \\
Ulborg & Forest & $2005-2009$ & Daily & Filter pack \\
& & $2005-2009$ & Half monthly & Denuder \\
Hjelm Hede & Heath land & $2005-2006$ & Half monthly & Denuder \\
Idom Hede & Heath land & $2005-2009$ & Half monthly & Denuder/ALPHA \\
Husby & Heath land, coast & $2006-2007$ & Half monthly and & ALPHA \\
& & & winter time monthly & \\
Lønborg Hede & Heath land & $2006-2007$ & Half monthly and & ALPHA \\
& & & winter time monthly & \\
Ovstrup Hede & Heath land & $2006-2007$ & Half monthly and & ALPHA \\
Bisgyde & Dry grassland & $2007-2009$ & Monthly & ALPHA \\
Diesbjerg & Heath land & $2007-2009$ & Monthly & ALPHA \\
Hammer Bakker & Heath land & $2007-2009$ & Monthly & ALPHA \\
Helm Polde & Heath land & $2007-2008$ & Monthly & ALPHA \\
Holmkær & Meadow & $2007-2008$ & Monthly & ALPHA \\
Nybo Mose & Raised bug & $2007-2009$ & Monthly & ALPHA \\
Randbøl Hede & Heath land & $2007-2009$ & Monthly & ALPHA \\
Råbjerg Mose & Raised bug & $2007-2009$ & Monthly & ALPHA \\
Storelung & Raised bug & $2007-2009$ & Monthly & ALPHA \\
Ulvholm & Rich fen & $2007-2009$ & Monthly & ALPHA \\
Ulvshale & Heath land & $2007-2008$ & Monthly & ALPHA \\
\hline & & & &
\end{tabular}

* The measuring period used in this study. At some of the sites, the measuring period is longer (see http://www.dmu.dk/en/Air/Monitoring/Programmes/).

Table 2. A short description of the 16 different functions describing the temporal variation in $\mathrm{NH}_{3}$ emissions from various activities (similar to Table 1 in Skjøth et al., 2011).

\begin{tabular}{ll}
\hline Function & Description \\
\hline Fkt 1 & Animal houses with forced ventilation \\
Fkt 2 & Open animal houses (non-forced ventilation) \\
Fkt 3 & Manure storages \\
Fkt 4 & Winter crops \\
Fkt 5 & Spring crops \\
Fkt 6 & Late spring crops \\
Fkt 7 & Grass \\
Fkt 8 & Spring application of manure on bare soil \\
Fkt 9 & Application of manure on crops \\
Fkt 10 & Summer application of manure \\
Fkt 11 & Autumn application of manure \\
Fkt 12 & Spring application of fertilizer (90\% of all fertilizer) \\
Fkt 13 & Summer application of fertilizer (10\% of all fertilizer) \\
Fkt 14 & Emissions related to grassing cattle \\
Fkt 15 & Emissions related to ammonia treated straw \\
Fkt 16 & Emissions related to personal vehicles with catalytic converters \\
\hline
\end{tabular}

5. meteorological data for the specific year, which are used for estimating the temporal variations of the emissions.

The most recent inventory available for this study is for 2007 . For the total national emission, the uncertainty is assumed to be in the range of $5-10 \%$, while the uncertainty on farm/field level is in the range of $25-35 \%$. The applied activity data (number of animals, etc) have a high precision as a result of the environmental regulation in Denmark that enforces Danish farmers to report very complete information. Most of the uncertainty therefore relates to the applied emission factors (Nielsen et al., 2011).

\subsection{The Danish Ammonia Modelling System}

The Danish Ammonia Modelling System (DAMOS) is a coupled system consisting of the regional air pollution model DEHM and the local-scale dispersion and deposition model OML-DEP. The overall structure of DAMOS, the necessary 
input data to the models and the flow of information between the two models, is described in the following.

\subsubsection{The DEHM model}

The Danish Eulerian Hemispheric Model (DEHM) is a 3-D Eulerian transport model covering the Northern Hemisphere. The model exists today in several versions and has through the years been applied for numerous studies, for example studies of transport of air pollution to the Arctic (Christensen, 1997; Christensen et al., 2004; Genualdi et al., 2011; Hansen et al., 2008), for analyses of atmospheric $\mathrm{CO}_{2}$ over Europe (Geels et al., 2004; Geels et al., 2007), for health assessments (Brandt et al., 2011) and for studying the future air pollution levels in a changed climate (Hedegaard et al., 2008; Hedegaard et al., 2011; Langner et al., 2012). Furthermore, the model is used in a model system, THOR, integrating the regional-scale with an urban background model and an urban street canyon model (Brandt et al., 2001). This system is applied for describing the air pollution in cities, taking into account higher resolution emissions as well as different physical local-scale characteristics (as e.g. dispersion) similar to the DAMOS system. In relation to nitrogen, the model has been used for several studies related to e.g. impact studies in the Arctic (Forsius et al., 2010) and projections of the $\mathrm{N}$ load to the Baltic Sea (Geels et al., 2012). The model is on a yearly basis applied in the Danish Background Air Quality Monitoring Program for calculations of nitrogen depositions to the Danish land and sea areas (Ellermann et al., 2009).

In the current study, the chemistry version of DEHM is applied, including 67 chemical compounds and 122 chemical reactions (Brandt et al., 2012; Christensen, 1997; Frohn et al., 2002). The horizontal resolution is $150 \mathrm{~km} \times 150 \mathrm{~km}$ in the mother domain, and the setup includes three nested domains with the highest resolution of $5.56 \mathrm{~km} \times 5.56 \mathrm{~km}$ over Denmark. Vertically, the model is divided into 29 unevenly distributed $\sigma$-levels, with the highest resolution towards the ground (lowest level is approximately $25 \mathrm{~m}$ thick). The necessary meteorological input is provided by the MM5v3 model (Grell et al., 1995), with a setup of grid definition and model domains that is identical to the DEHM model.

The emissions of the primary pollutants $\left(\mathrm{NH}_{3}, \mathrm{NO}_{\mathrm{x}}, \mathrm{SO}_{2}\right.$, $\mathrm{CO}, \mathrm{CH}_{4}, \mathrm{VOC}, \mathrm{PM}_{2.5}, \mathrm{PM}_{10}$ and TSP) are based on a combination of the EMEP (European Monitoring and Evaluation Programme; Mareckova et al., 2008) and RCP (Representative Concentration Pathways; Lamarque et al., 2010) emission inventories. Natural emissions of $\mathrm{NH}_{3}$ and $\mathrm{NO}_{\mathrm{x}}$ are taken from the GEIA database (Global Emission Inventory Activity; Graedel et al., 1993), while emissions from wildfires are based on Schultz et al. (2008). For the Danish area, the dynamical ammonia emission model described in Sect. 2.2 is applied as well as detailed emissions from ships (Olesen et al., 2009). Also, other anthropogenic emissions are for the Danish area included with a higher resolution where possible. Emissions from road traffic are in- cluded on resolution of $1 \mathrm{~km} \times 1 \mathrm{~km}$, while other emissions sources like industry, power plants, etc. are included on a $16.67 \mathrm{~km} \times 16.67 \mathrm{~km}$ grid, based on results from the HYSCENE project (Jensen et al., 2010).

Dry deposition velocities for the gaseous compounds are based on the methodology applied in the EMEP Unified model (Simpson et al., 2003). The dry deposition is calculated for 16 land-use categories, where the surface resistance is divided into a stomatal and a nonstomatal component. For $\mathrm{NH}_{3}$ the nonstomatal component includes, among other things, an acidity ratio between $\mathrm{SO}_{2}$ and $\mathrm{NH}_{3}$ (Emberson et al., 2000; Simpson et al., 2003), while a stomatal compensation point is not included. Wet deposition processes in DEHM include in-cloud and below-cloud scavenging of particles and gases.

In previous studies, DEHM has been validated against measured depositions and concentrations of various nitrogen components across the EMEP measuring sites in Europe, and the model is seen to capture the overall measured patterns (Brandt et al., 2012; Geels et al., 2005; Pul et al., 2009a). In a recent study, measurements of air concentrations and wet depositions of nitrogen components, covering the years 1990-2009 at the five main monitoring sites in Denmark, have been used for validation of DEHM with a resolution of $16.67 \mathrm{~km} \times 16.67 \mathrm{~km}$ over Northern Europe (Geels et al., 2012). Dry deposition fluxes have not been measured, but by applying the dry deposition velocities from the model, the measured air concentrations are converted to dry deposition fluxes, and the estimates of the annual total nitrogen deposition to land areas and marine areas have been compared to the model results for the same areas. As an average over the full period, the model tends to overestimate the estimated deposition to land areas by $20 \%$ and underestimate the deposition with approximately $10 \%$ at the marine sites. The uncertainty related to the estimates of the total nitrogen deposition is discussed in Sect. 5.

\subsubsection{OML-DEP and the coupling to DEHM}

OML-DEP is an extension of the OML model, which is a Gaussian plume model used for modelling of atmospheric dispersion on the local scale of up to ca. $20 \mathrm{~km}$ from point and area sources (Olesen et al., 1992). It is the recommended model to be used for environmental impact assessments when new industrial sources are planned in Denmark. OML-DEP has been developed in order to include dry deposition of ammonia on local scale applying high resolution land-use data for Denmark (Nielsen et al., 2000) and the previously described dynamical ammonia emission model.

In DAMOS, the DEHM and OML-DEP models use the same input data and parameterisations, to the extent that it is possible, in order to ensure consistency. Hence, the dry deposition of $\mathrm{NH}_{3}$ is in OML-DEP parameterised in the same way as in the regional model. Similarly, the applied meteorology is the same in OML-DEP and the DEHM model in the 
form of hourly time series of relevant meteorological parameters extracted from the MM5v3 fields with a resolution of $5.56 \mathrm{~km} \times 5.56 \mathrm{~km}$ over Denmark. In OML-DEP the chemical transformation of $\mathrm{NH}_{3}$ to $\mathrm{NH}_{4}^{+}$is calculated by a firstorder reaction velocity (Asman et al., 1989), which on average reduces the $\mathrm{NH}_{3}$ concentration with about $10 \%$ within transport distances of $8 \mathrm{~km}$. Wet removal of ammonia has been disregarded in the local-scale model.

The OML-DEP model uses a quadratic grid with $40 \times 40$ receptor points. In DAMOS, OML-DEP is applied for a $16 \mathrm{~km} \times 16 \mathrm{~km}$ domain centred at the monitoring site or nature area in focus. This gives a grid resolution of $400 \mathrm{~m} \times 400 \mathrm{~m}$ in the resulting concentrations and depositions, which is considered to give a reasonable coverage of the local-scale sources and the transport and transformation of $\mathrm{NH}_{3}$ near these sources. In order to account for the medium to long-range transport of ammonia from sources outside the OML-DEP domain, time series of $\mathrm{NH}_{3}$ concentrations are provide by the DEHM model. The hourly time series are interpolated from the DEHM grid at the upwind border of the OML-DEP domain and averaged over the boundary layer. Likewise, hourly time series of surface concentrations of $\mathrm{SO}_{2}$ are provided by DEHM for the acidity ratio in the dry deposition formulation. Due to the low $\mathrm{SO}_{2}$ concentrations in Denmark, the ratio rarely has any impact on the depositions. A one-way coupling between the models is used.

The coupled model system DAMOS has previously been tested in connection with a measuring campaign around a poultry farm in Denmark, where it was shown that the model calculations clearly reflected the measured $\mathrm{NH}_{3}$ concentration and $\mathrm{N}$ deposition around the farm (Sommer et al., 2009).

\section{Results}

\subsection{Spatial patterns}

Examples of the model results are displayed in Fig. 1 and 2 for the year 2007. The spatial patterns of $\mathrm{NH}_{3}$ concentrations (lowest model layer) and the total $\mathrm{N}$ deposition across the Danish land areas estimated by the regional model are shown in Fig. 1c and d. In both maps, a gradient across Denmark is seen with highest depositions in the southwestern part of the country. This gradient is caused partly by atmospheric transport of mainly $\mathrm{NO}_{\mathrm{x}}$ (and its reaction products) from Northern Europe and partly by the local ammonia emissions (Fig. 1b) that are highest in this agricultural part of Denmark. In 2007 the $\mathrm{N}$ load was more than $20 \mathrm{~kg} \mathrm{Nha}^{-1}$ in the southern part of Jutland, close to the German boarder.

The geographical distribution of the $\mathrm{NH}_{3}$ concentration and dry deposition can be estimated in more detail with the OML-DEP model. An example is seen in Fig. 2c and d, which show the annual mean concentration and dry deposition in the $16 \mathrm{~km} \times 16 \mathrm{~km}$ area surrounding the measuring site Tange. The spatial distribution of the $\mathrm{NH}_{3}$ concentrations and depositions follow the distribution of the emissions closely (Fig. 2b). The highest concentrations and depositions of more than $5 \mu \mathrm{g} \mathrm{NH} \mathrm{NH}_{3}-\mathrm{Nm}^{-3}$ and up to ca. $40 \mathrm{~kg} \mathrm{NH}_{3}$ $\mathrm{N} \mathrm{ha}^{-1}$ are seen around the point sources (animal houses and manure storages), with a steep decrease in the concentration/deposition with distance from the source. Spatial variability in the deposition field is also seen due to variations in the surface characteristics (a few land-use characteristics are shown in Fig. 2a) with low depositions, e.g. over the lake central in the model domain and relative higher depositions in forested areas east of the lake.

\subsection{Temporal patterns}

\subsubsection{Inter-annual variations}

In Fig. 4 the measured and modelled annual mean concentrations of ammonia at the five main Danish monitoring stations are shown for the period 2005-2009. The model results from DAMOS are shown as the yearly value at the receptor point located at the monitoring station, while the results from the DEHM model are interpolated from the model grid to the location of the stations.

Lowest levels in the range $0.14-0.19 \mu \mathrm{g} \mathrm{NH}_{3}-\mathrm{N} \mathrm{m}^{-3}$ are measured on the island Anholt, while the highest levels of up to $1.63 \mu \mathrm{g} \mathrm{NH}-\mathrm{N} \mathrm{m}^{-3}$ are measured at Lindet in the southern part of Jutland, where the levels in general are high (see Fig. 1.). Generally, the DAMOS system (including both DEHM and OML-DEP) captures the measured concentrations better than DEHM alone. This is especially the case at the Lindet site where the yearly level is captured within $5 \%$, when averaged over the full period. At Anholt the levels are on average underestimated by $12 \%$, while the $\mathrm{NH}_{3}$ levels are overestimated by about $19 \%$ at the Keldsnor and Tange sites. At the Ulborg site, the measured levels are overestimated on average by about $53 \%$. The DEHM model overestimates by $30-50 \%$ at four of the sites and by up to $114 \%$ at the Ulborg site. In the individual years, the DAMOS and DEHM numbers can be in better/worse agreement with the observations. An example is 2007, where the DAMOS model captures the measured levels at Anholt, Keldsnor, Lindet and Tange within $\pm 15 \%$.

In Fig. 4 the annual concentration from DAMOS is also included as an average over a $6 \mathrm{~km}$ area centred at the measuring sites. This "DAMOS mean $6 \mathrm{~km}$ " is seen to be very close to the results from the DEHM model.

DAMOS use reported $\mathrm{NH}_{3}$ emission from 2007 to cover the calculations for the years 2007, 2008 and 2009. The differences in the model results between 2007, 2008 and 2009 are therefore driven by meteorological variations alone. At the Lindet and Ulborg sites, these variations lead to approximately 7-17\% higher concentrations in 2008-2009 in the models. At the other sites, the variability is between $-8 \%$ and $8 \%$. 


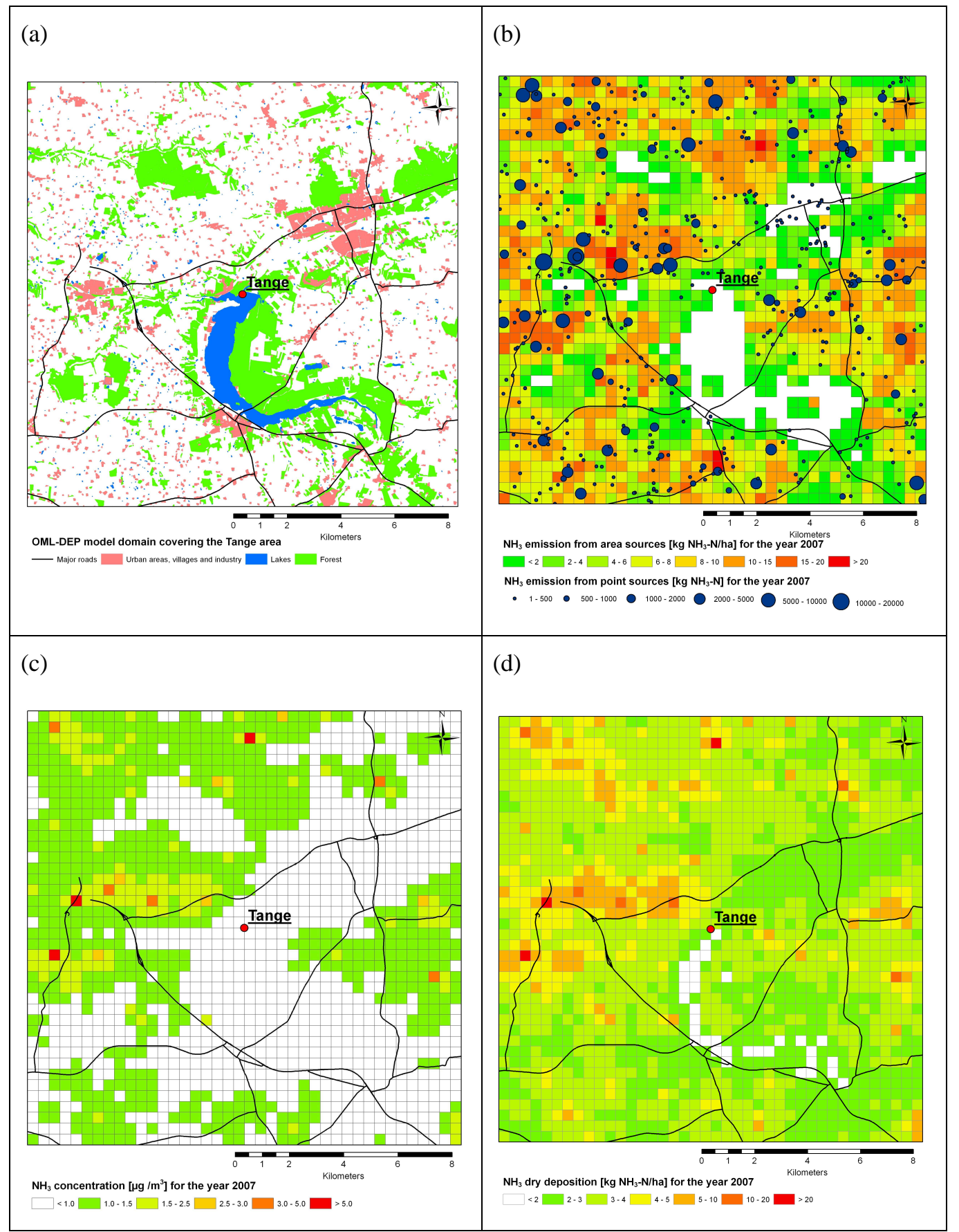

Fig. 2. (a) The OML-DEP $16 \mathrm{~km} \times 16 \mathrm{~km}$ model domain centered around the Tange site. The resolution in the local-scale model is $400 \mathrm{~m} \times 400 \mathrm{~m}$. (b) The applied $\mathrm{NH}_{3}$ emissions divided into area and point sources for the year 2007. (c) The yearly averaged $\mathrm{NH}_{3}$ concentration as calculated by the DAMOS system for the year 2007. (d) The yearly total dry deposition of $\mathrm{NH}_{3}$ as calculated by the DAMOS system for the year 2007 .

\subsubsection{Intra-annual variations}

The DAMOS system is also evaluated on the seasonal time scale by using the mainly half monthly to monthly data from all the Danish sites (Fig. 5). Statistical data for the correspon- dence between both models and the measured time series are given in Table 3, and time series of the $\mathrm{NH}_{3}$ concentration at four sites are shown in Fig. 6 as an example.

From this evaluation, it can be seen that the overall measured patterns with a main peak in spring, a few less 


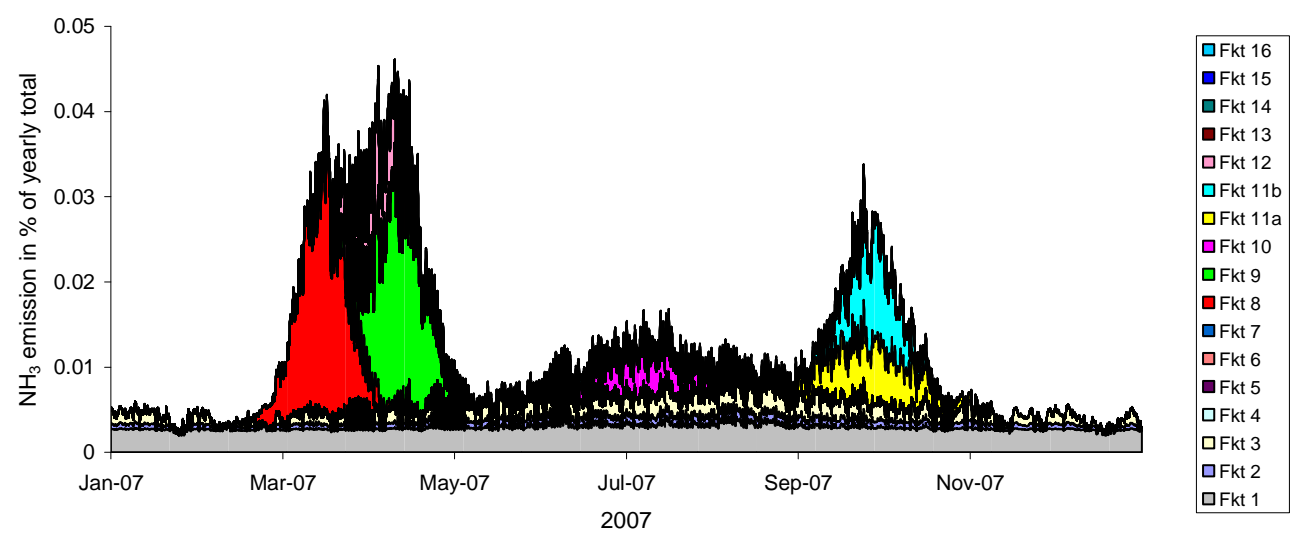

Fig. 3. Seasonal variations of the hourly $\mathrm{NH}_{3}$ emissions separated into the various agricultural emission categories (described in Table 2) in the applied emission parameterisation. The emissions are shown as percentage of the yearly sum of all the 16 categories for the Tange site in the year 2007 .

Table 3. Statistical evaluation of the comparison between measurements (meas) and DAMOS or DEHM. The statistical parameters given are mean values, bias (= model mean - meas mean), variance and correlation coefficients $(r)$ based on the Pearson method. See Table 1 for details about the sites (denuder and ALPHA data are included here). The bold numbers indicates best performance in the evaluation (that is lowest bias and highest correlation coefficient).

\begin{tabular}{|c|c|c|c|c|c|c|c|c|c|c|}
\hline \multirow{2}{*}{$\begin{array}{l}\text { Parameter } \\
\text { Station }\end{array}$} & \multicolumn{3}{|c|}{ Mean } & \multicolumn{2}{|c|}{ Bias } & \multicolumn{3}{|c|}{ Variance } & \multicolumn{2}{|c|}{ Correlation } \\
\hline & meas. & DAMOS & DEHM & DAMOS & DEHM & meas. & DAMOS & DEHM & meas - DAMOS & meas - DEHM \\
\hline Anholt & 0.22 & 0.15 & 0.22 & -0.07 & 0.00 & 0.03 & 0.01 & 0.01 & 0.67 & 0.80 \\
\hline Bisgyde & 0.51 & 0.69 & 0.89 & 0.18 & 0.38 & 0.12 & 0.38 & 0.45 & 0.90 & 0.90 \\
\hline Diesbjerg & 0.71 & 0.73 & 0.66 & 0.02 & -0.05 & 0.26 & 0.49 & 0.26 & 0.85 & 0.86 \\
\hline Hammer Bakker & 0.54 & 1.01 & 1.50 & 0.47 & 0.95 & 0.16 & 0.71 & 1.10 & 0.94 & 0.94 \\
\hline Helm Polde & 0.97 & 1.38 & 1.97 & 0.42 & 1.01 & 0.35 & 0.87 & 1.37 & 0.84 & 0.84 \\
\hline Hjelm Hede & 1.17 & 1.19 & 1.49 & 0.02 & 0.33 & 0.62 & 0.74 & 1.19 & 0.77 & 0.55 \\
\hline Holmkær & 0.84 & 0.85 & 0.91 & 0.01 & 0.07 & 0.29 & 0.47 & 0.33 & 0.93 & 0.90 \\
\hline Husby & 0.63 & 0.68 & 1.01 & 0.04 & 0.38 & 0.29 & 0.28 & 0.62 & 0.94 & 0.92 \\
\hline Idom Hede & 1.08 & 1.19 & 1.43 & 0.11 & 0.35 & 0.43 & 0.71 & 0.88 & 0.84 & 0.80 \\
\hline Keldsnor & 0.68 & 0.77 & 0.86 & 0.09 & 0.18 & 0.26 & 0.40 & 0.31 & 0.67 & 0.69 \\
\hline Lindet & 1.31 & 1.41 & 1.94 & 0.11 & 0.64 & 0.93 & 1.30 & 1.66 & 0.72 & 0.67 \\
\hline Lønborg Hede & 1.12 & 1.63 & 1.78 & 0.51 & 0.66 & 0.32 & 1.01 & 1.32 & 0.77 & 0.81 \\
\hline Nybo Mose & 0.74 & 0.97 & 1.25 & 0.23 & 0.52 & 0.25 & 0.50 & 0.65 & 0.88 & 0.86 \\
\hline Ovstrup Hede & 1.22 & 1.66 & 2.18 & 0.44 & 0.96 & 0.26 & 0.87 & 1.50 & 0.79 & 0.69 \\
\hline Raabjerg Mose & 0.28 & 0.96 & 1.06 & 0.68 & 0.78 & 0.04 & 0.37 & 0.36 & 0.77 & 0.82 \\
\hline Randbol Hede & 0.59 & 0.84 & 1.16 & 0.25 & 0.57 & 0.14 & 0.29 & 0.45 & 0.88 & 0.85 \\
\hline Storelung & 0.97 & 1.76 & 1.77 & 0.79 & 0.79 & 0.49 & 2.76 & 1.57 & 0.80 & 0.84 \\
\hline Ulborg & 0.54 & 0.88 & 1.23 & 0.34 & 0.69 & 0.26 & 0.47 & 0.70 & 0.83 & 0.81 \\
\hline Ulvholm & 0.84 & 1.64 & 1.94 & 0.81 & 1.11 & 0.26 & 1.96 & 1.52 & 0.88 & 0.88 \\
\hline Ulvshale & 0.41 & 0.39 & 0.50 & -0.03 & 0.09 & 0.05 & 0.05 & 0.07 & 0.86 & 0.87 \\
\hline
\end{tabular}

pronounced peaks throughout late summer and autumn, and low concentrations during the winter months are captured by both models. Correlation coefficients of $0.67-0.94$ are obtained for the DAMOS system, while the regional model obtains correlation coefficients in the range of $0.55-0.94$. As seen in Table 3, improved correlations are obtained at some stations in the DAMOS simulations compared to DEHM alone, but at other stations the opposite can be the case. A clearer picture is seen for the bias (model mean-measured mean), which for the majority of the stations is smallest with the simulations from DAMOS. From the time series in Fig. 6, it is seen that both models tend to overestimate the overall level during the spring and summer months, while the measured level is better captured by the models (especially DAMOS) during winter.

\subsection{Direct impact of local emissions}

In spite of the high-resolution $\mathrm{NH}_{3}$ emission inventory (Fig. 1b.) applied for Denmark in the DEHM model, some of the heterogeneity in the emissions near a given site will 


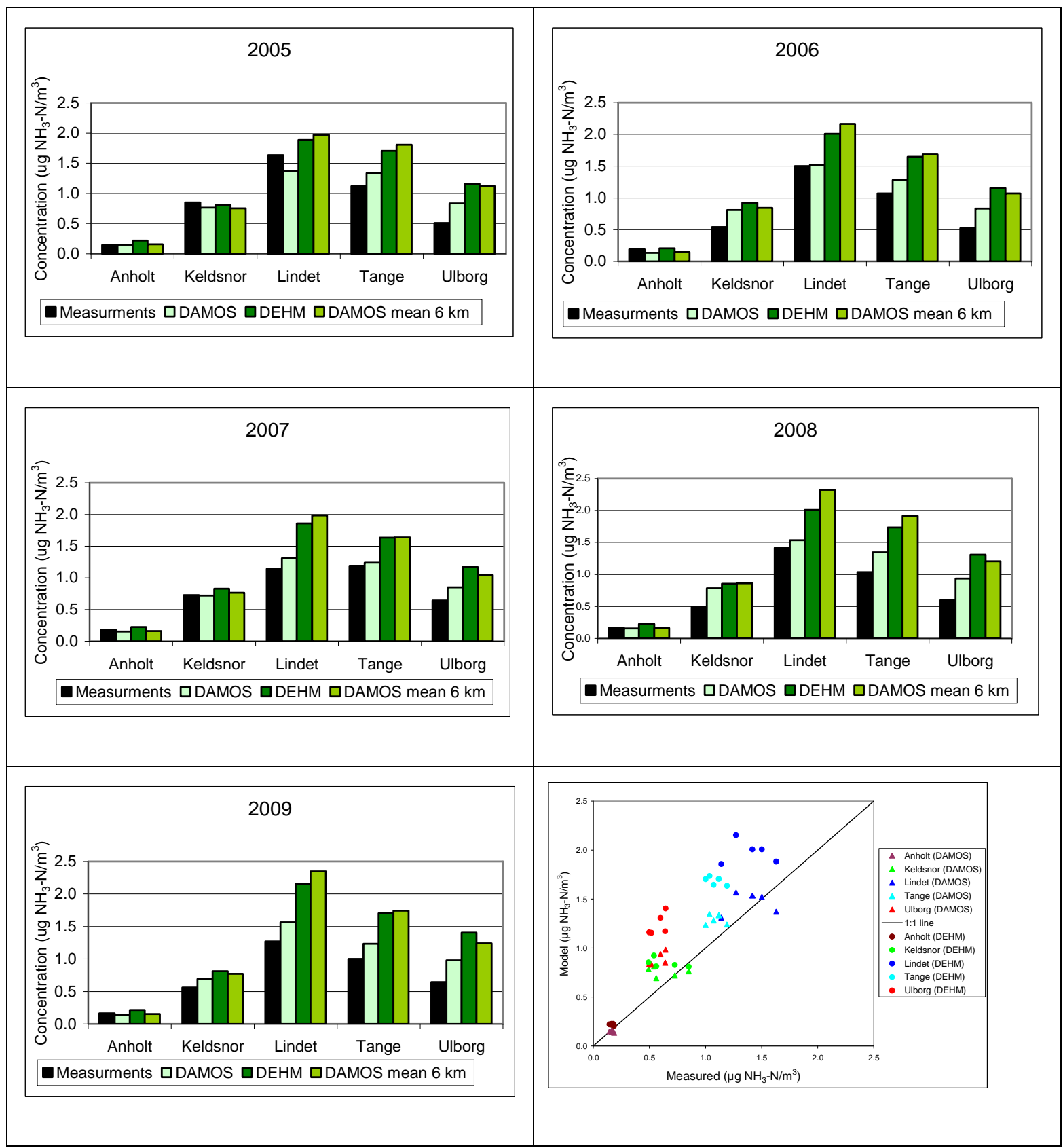

Fig. 4. Measured and modelled yearly $\mathrm{NH}_{3}$ concentrations at the five main monitoring sites as a column diagram for each of the years 2005-2009 and collected in a scatter diagram.

be lost in the $5.56 \mathrm{~km} \times 5.56 \mathrm{~km}$ model simulations. This is likely part of the reason why the regional model in general overestimates the observed $\mathrm{NH}_{3}$ level more than the high resolution DAMOS simulations. This is supported by the fact that the DAMOS results averaged over a $6 \mathrm{~km} \times 6 \mathrm{~km}$ is very similar to the DEHM results. However, in order to confirm this, the distribution of the local emissions has to be viewed in detail at each site.
In order to illustrate the density of the local $\mathrm{NH}_{3}$ emissions around the five main sites, the emission within circle areas around each site has been calculated. Based on the $\mathrm{NH}_{3}$ inventory used in DAMOS, the emission per ha for five circle areas with radius from $500 \mathrm{~m}$ to about $8000 \mathrm{~m}$ and centred at the measuring site is displayed in Fig. 7 (the total emission is also given in Table 4). The resolution of the DAMOS model is $400 \mathrm{~m} \times 400 \mathrm{~m}$, so the inner circle closest to the centre illustrates the emission that directly influences 


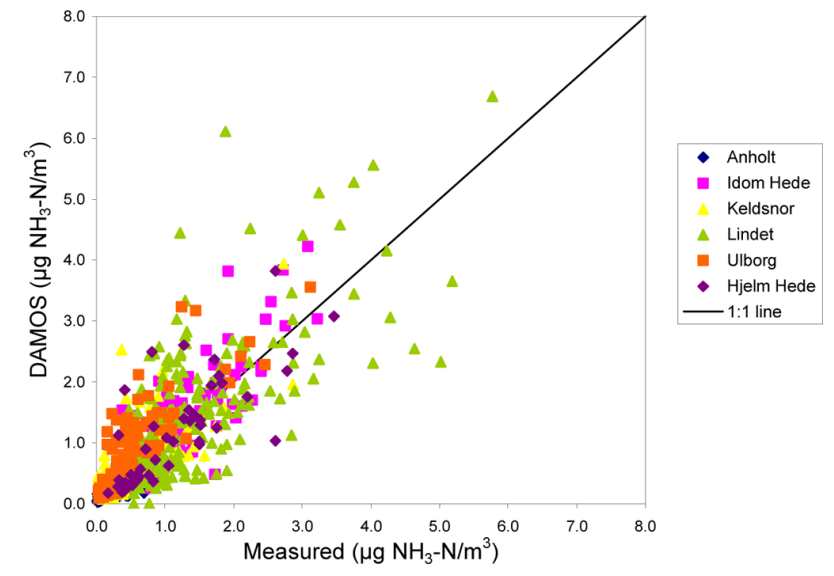

(a)

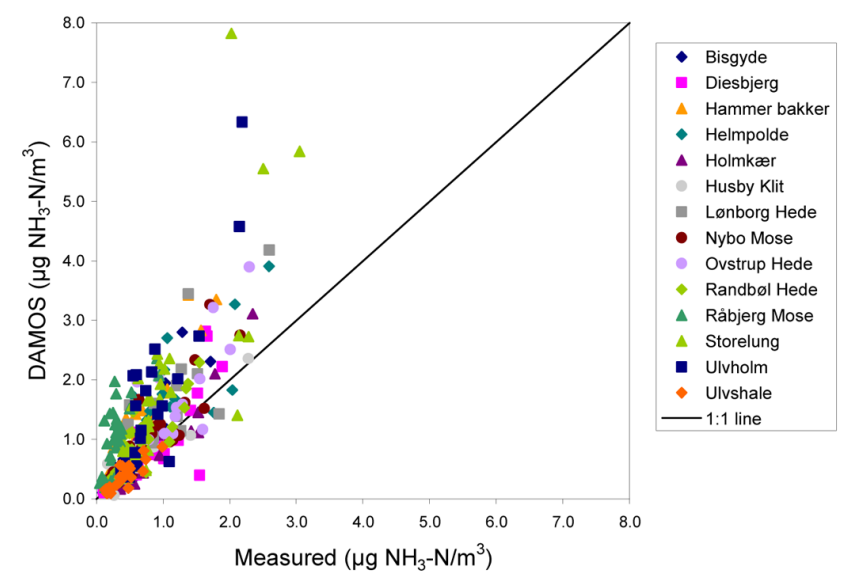

(b)

Fig. 5. Measured and modelled monthly or 1/2 monthly concentrations at the Danish sites (a) where the denuder method has been applied and (b) where the passive diffusion tube samplers ALPHA have been applied (see also Table 1 for more details about each site and Table 3 for the statistical evaluation).

the concentration in the centre. The regional model has a resolution of $5.56 \mathrm{~km} \times 5.56 \mathrm{~km}$, and the concentration at the measuring site is found by interpolation between the nearest grid points. The emissions directly influencing this concentration will therefore be represented by the circles with a radius between ca. $2000 \mathrm{~m}$ to $5000 \mathrm{~m}$.

Based on the results in Fig. 7 and the results described above, the following can be seen:

- The local area emission per ha is small within the first $1000 \mathrm{~m}$ from the main sites, with only a small contribution from area sources. This is in accordance with the fact that the locations of the sites have been carefully selected in order to minimize the impact from larger local sources like farms.
- The local emissions in the Anholt area are seen to be very close to zero. At the other sites, we see a steep increase in the emissions per ha from around $1000 \mathrm{~m}$ to $2000 \mathrm{~m}$. These emissions are in DEHM, instantly distributed in a grid cell of $5.56 \mathrm{~km} \times 5.56 \mathrm{~km}$ and a layer thickness of $25 \mathrm{~m}$ and will directly influence the concentration calculated by the DEHM model. This will lead to higher $\mathrm{NH}_{3}$ concentrations than obtained with the DAMOS model.

- The local-scale model has a more realistic dispersion both horizontally and vertically close to the sources. This is, for example, seen in the time series (Fig. 6.) where DEHM at the Lindet and Ulborg sites especially overestimates the peaks during spring to autumn, implying a too high impact of local emissions that are highest during this time of year.

It should be noted that this analysis does not take the combined effect of location of source and wind direction into account. For example, a farm located upwind of the measuring site will have more impact on the measured ammonia levels than a farm located downwind from the site.

\subsection{Local emissions versus non-local emissions}

In order to answer the question "why not only use a localscale model", we have utilized the DAMOS system with and without local emissions. Thereby, we can identify the impact of local emissions versus non-local emissions. The local emissions are here defined as the $\mathrm{NH}_{3}$ emissions included in a given DAMOS domain $(16 \mathrm{~km} \times 16 \mathrm{~km})$, while the nonlocal emissions refer to all $\mathrm{NH}_{3}$ emissions upstream from this domain that will have an impact on the $\mathrm{NH}_{3}$ background concentration provided by the DEHM model at the boundary of the local-scale model. In Fig. 8 the resulting yearly $\mathrm{NH}_{3}$ concentrations and depositions at the five main sites are shown for the two different model runs.

As expected from the analysis in Sect. 3.3, the Anholt site is controlled by inflow from non-local sources. At the four other sites, the background contributes with about $50 \%$ of the overall $\mathrm{NH}_{3}$ concentration/deposition. Small differences in the impacts are, however, seen as the local signal dominates at the Lindet and Tange sites, while the background signal slightly dominates at the Keldsnor and Ulborg sites. When comparing the absolute values in Fig. 8, the background level as well as the local contribution is seen to be highest at the Lindet and Tange sites, which is in agreement with the regional-scale emissions (Fig. 1) and the local emissions (Fig. 7).

These model results can also be used to estimate the fraction of locally emitted $\mathrm{NH}_{3}$ that is dry deposited locally within the model domain. In Table 4, the yearly dry deposition is calculated for each site as a sum over all the grid cells in a given $16 \mathrm{~km} \times 16 \mathrm{~km}$ domain. Also, the total annual emissions within the domains are given. From these two 

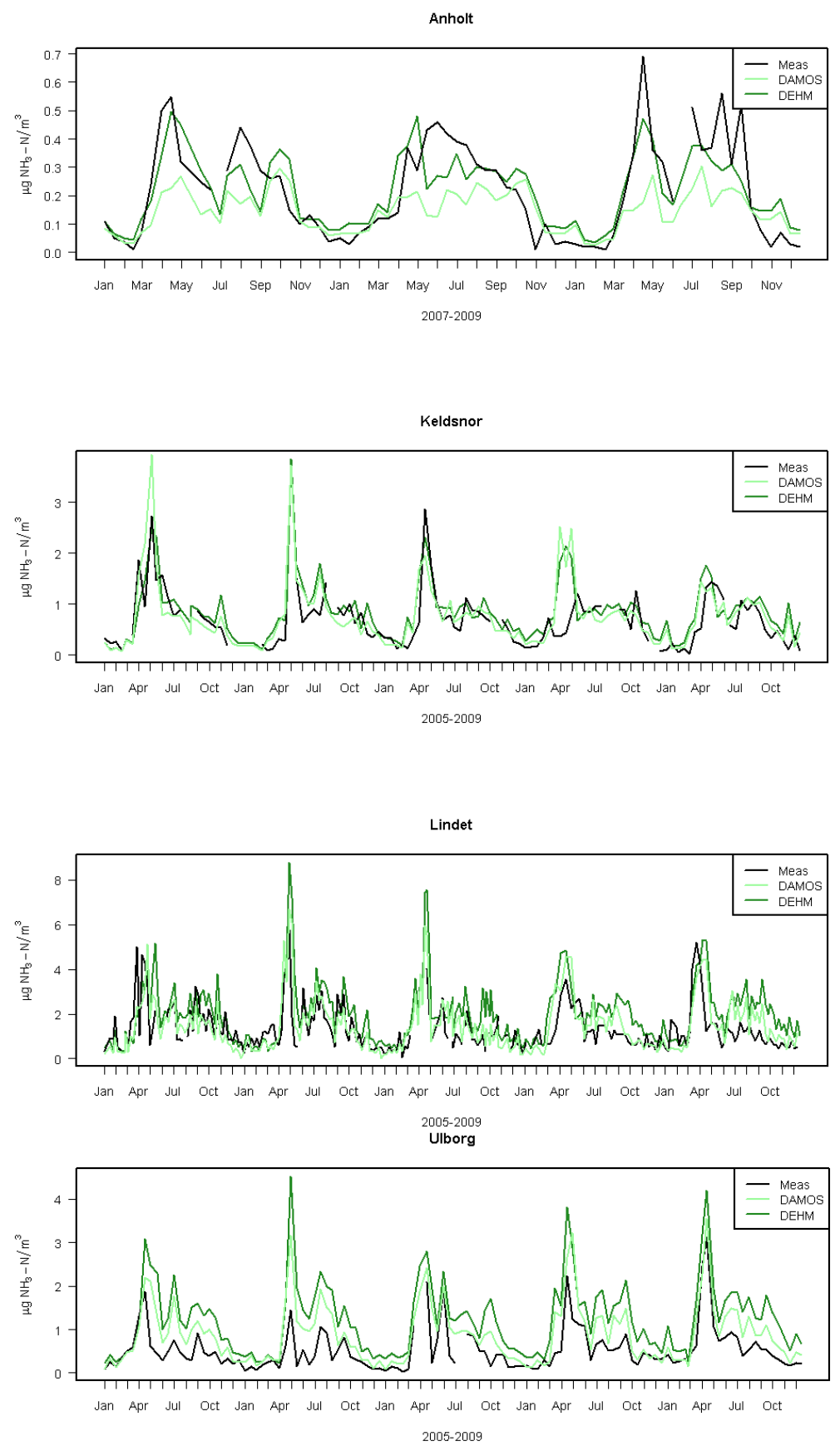

Fig. 6. Time series of measured and modelled $\mathrm{NH}_{3}$ concentrations at four sites in Denmark covering the period 2005-2009 or 2007-2009. At the Lindet site, mean weekly samples are shown, while at Anholt, Keldsnor and Ulborg 1/2 monthly samples are displayed.

sets of numbers, we can calculate that about $14 \%$ to $27 \%$ of the locally (that is within a radius of about $8 \mathrm{~km}$ ) emitted $\mathrm{NH}_{3}$ is also deposited locally at the five sites in focus here.

\section{Discussion}

Comparing the observed and calculated concentrations of ammonia at a number of sites in Denmark shows that our overall initial goal is met: the annual to monthly ammonia concentrations calculated with the DAMOS system, which couples regional and local-scale models, generally matched the observed levels better than values based on the regional model alone. However, both models tend to overestimate the observed levels. The improved performance of the DAMOS system was most pronounced at sites located in agricultural regions. In the past, regional-scale CTMs have been found to underestimate the observed concentration of $\mathrm{NH}_{3}$ due to 
Table 4. The modelled annual $\mathrm{NH}_{3}$ deposition within the OML-DEP domain related to the local emissions alone. Given as both $\mathrm{kg} \mathrm{Nha}^{-1} \mathrm{yr}^{-1}$ and as $\%$ of the $\mathrm{NH}_{3}$ emitted from local sources.

\begin{tabular}{lccc}
\hline Station & Deposition due to local emissions & Local emissions & Local emissions dep. in domain \\
\hline Unit & $\mathrm{kg} \mathrm{N} \mathrm{ha}^{-1} \mathrm{yr}^{-1}$ & $\mathrm{~kg} \mathrm{~N} \mathrm{ha}^{-1} \mathrm{yr}^{-1}$ & $\%$ \\
Anholt & $6.4 \mathrm{E}-04$ & $2.4 \mathrm{E}-03$ & 27 \\
Keldsnor & $4.0 \mathrm{E}-01$ & 2.1 & 19 \\
Lindet & 2.5 & 17.4 & 14 \\
Tange & 2.3 & 15.1 & 15 \\
Ulborg & 1.6 & 11.4 & 14 \\
\hline
\end{tabular}

the relative coarse resolution of e.g. $50 \mathrm{~km} \times 50 \mathrm{~km}$ (Pul et al., 2009b). In the current setup, a much higher resolution is applied in the CTM over Denmark and the regional model tends to overestimate the $\mathrm{NH}_{3}$ levels. In the Danish area with many agricultural sources, the direct impact of local emissions becomes too high when applying a $5.56 \mathrm{~km} \times 5.56 \mathrm{~km}$ grid resolution in the model. However, by coupling the regional model to the local-scale model, the emissions pattern was resolved in greater detail and the resulting concentrations matched the levels better (the bias is smaller at a majority of the sites). Similarly, Fournier et al. (2002) concluded that a $5 \mathrm{~km} \times 5 \mathrm{~km}$ resolution model for the British Isles did not fully describe the local variability observed. Dragosits et al. (2002) extended the study and applied a local-scale atmospheric dispersion model for $\mathrm{NH}_{3}$ at a higher spatial resolution $(50 \mathrm{~m} \times 50 \mathrm{~m})$. They concluded again that the local variability is high and that the national assessments at the $5 \mathrm{~km}$ grid in the UK will give an incomplete picture of the occurrence of critical load exceedances.

In relation to dry deposition and exceedances, it is important to resolve the surface roughness. The coupled system therefore also improved the result through its higher resolution of the surface roughness (land-cover) as seen in the example of the estimated dry deposition of ammonia in the OML-DEP domain centred at Tange (Fig. 2). Here, the high deposition areas close to the sources are clearly seen, but higher depositions can also be seen in the regions with forests (with high roughness).

At sites like Keldsnor, Anholt and Raabjerg Mose (located in areas with fewer local sources), the improvements by using the DAMOS system are less obvious. These sites are mainly influenced by regional to long-range transport of ammonia. In this case, the regional model captured the observed level, and the background level from DEHM dominated the signal from the coupled model. So, both the local-scale and regional-scale model are important for the results, while the relative importance of the local-scale versus the long-range contribution will vary depending on the emission density of a given area as well as on meteorological conditions (e.g. dominating wind speed/direction).
The pronounced intra-annual cycle of the ammonia concentration across Denmark is generally captured by the DAMOS system. Previous sensitivity studies with the DEHM model has shown that this variability is captured due to the detailed description of the spatial and temporal variation in the $\mathrm{NH}_{3}$ emissions (Skjøth et al., 2011). So far, the necessary high resolution emission data and detailed information on agricultural praxis are still only available in few European countries; effort is currently put into extending the data coverage (see e.g. Reis et al., 2012) with focus on the UK. The overestimation of the concentration in spring for DAMOS is likely caused by the spatial averaging of the area sources into the model grid. While the measuring sites are located at some distance from individual fields, the model results will be directly influenced by area sources within the $400 \mathrm{~m} \times 400 \mathrm{~m}$ central grid cell.

Modelling of the seasonal variability has importance as the dry deposition is calculated as a product of the concentration and a parameterized deposition velocity, which during Danish conditions has a seasonal variability due to a strong influence from humidity. Additionally, a future implementation of compensation points in the models gives a strong need for as good concentration estimations as possible. In relation to effects of nitrogen load/level to sensitive nature areas, this variability might be important to capture by models, as the plant sensitivity to the nitrogen load/level might differ throughout the year (Sheppard et al., 2009).

In relation to regulation of ammonia emissions, the range of influence of emitted $\mathrm{NH}_{3}$ is highly relevant and has been studied, e.g. by the use of various types of models. As previously mentioned, a review of a number of European models states that the fraction of $\mathrm{NH}_{3}$ that is recaptured locally is in the range of 2\%-60\% (Loubet et al., 2009). With the DAMOS model, we estimate that the fraction of locally emitted $\mathrm{NH}_{3}$ depositing locally is $14 \%-27 \%$ at five Danish locations. In a recent study for the US, Dennis et al. (2010) used the CMAQ model to estimate that about $8 \%-15 \%$ of the $\mathrm{NH}_{3}$ emitted within a $12 \mathrm{~km}$ grid cell is also deposited in the same cell. Model results by Kryza et al. (2011) covering Poland with at $5 \mathrm{~km} \times 5 \mathrm{~km}$ and the UK with $5 \mathrm{~km}$ and $1 \mathrm{~km}$ (Hallsworth et al., 2010) suggest that both large areas 

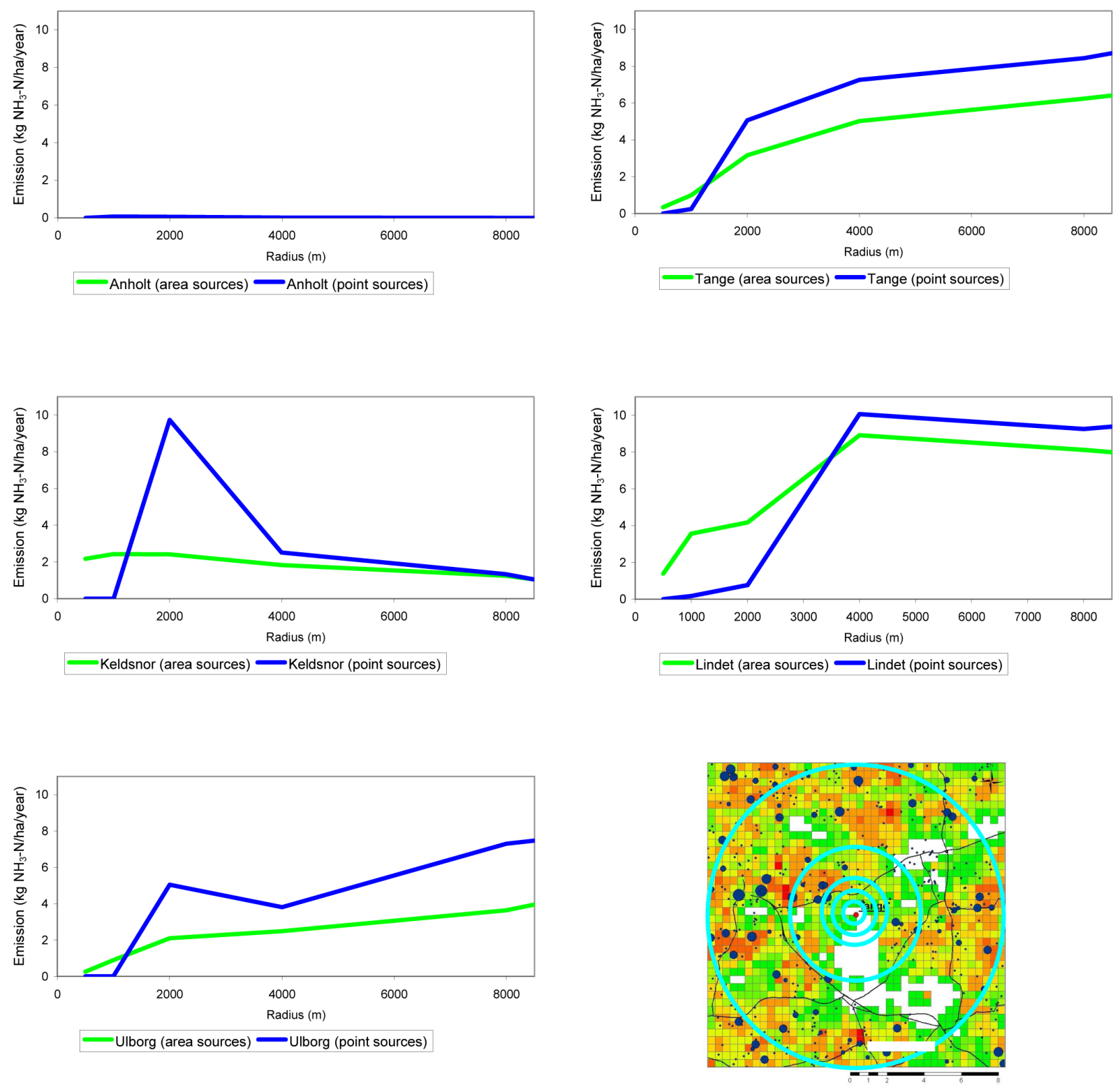

Fig. 7. The average emission of $\mathrm{NH}_{3}$ from area and point sources within different circle areas around each of the five main monitoring sites, based on the emissions used in DAMOS for the year 2007. The radii of the circle areas (centred around the sites) are given on the $\mathrm{x}$-axis, and the emissions are normalized by the circle area. Note that the emissions given at $8500 \mathrm{~m}$ are the sum over the full domain. The locations of the circle areas are shown together with the $\mathrm{NH}_{3}$ emissions for the domain at Tange as an illustration (lower right plot).

as well as smaller hot spots can have exceedances of critical loads due to intense agricultural production. These studies suggest that, near strong emission sources, a higher spatial resolution than $5 \mathrm{~km}$ is needed for a meaningful assessment of model-based critical loads to sensitive ecosystems. The studies by Kryza et al. (2011), however, also suggest that high spatial resolution modelling with transport models only makes sense, if this modelling is accompanied with equally high resolution in the emission inventories.

These results hence all confirm that $\mathrm{NH}_{3}$ emissions should not only be viewed and treated as a local problem, but also as an issue on the regional scale. As previously mentioned, part of the emitted $\mathrm{NH}_{3}$ in the atmosphere will be transformed into aerosols containing ammonium $\left(\mathrm{NH}_{4}^{+}\right)$. As the main removal path of these aerosols is wet deposition, they can be transported over long distances ( $>1000 \mathrm{~km}$ ) before being deposited (Hertel et al., 2006), which also supports that $\mathrm{NH}_{3}$ should be viewed in regional perspective. However, some of the problems in relation to excess nitrogen from agriculture can only be meaningfully solved by taking local variations into account. The studies presented here show that high resolution calculations that take both regional and local-scale 


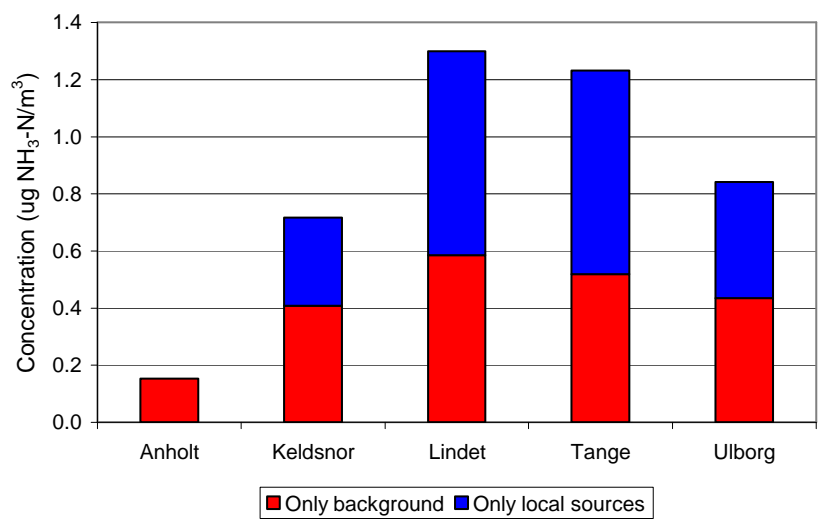

(a)

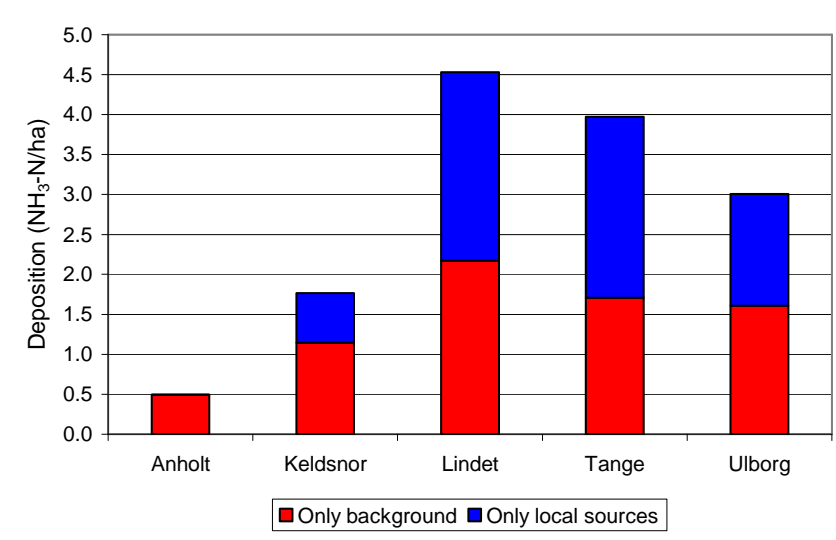

(b)

Fig. 8. The modelled $\mathrm{NH}_{3}$ concentration (a) and deposition (b) at the five main sites separated into "only background" and "only local sources" for the year 2007. The "background" refers to the part coming from non-local sources, i.e. due to $\mathrm{NH}_{3}$ transported into the OML-DEP domain from upwind sources in the DEHM model domain. The "local sources" refer to the part coming from the local $\mathrm{NH}_{3}$ emissions within the OML-DEP domain. The size of the local emissions can be seen in Fig. 7.

variations into account are technically possible without too large computational cost and that such calculations make scientifically sense, when high quality emission data are available. The regional model is run on a Linux cluster, while the local-scale model is run on a standard PC. For a given nature area, the local-scale calculations will take approximately 12 CPU hours.

It has long been acknowledged that the flux of ammonia can be bi-directional in agricultural areas (Farquhar et al., 1980). Like many other regional models (Massad et al., 2010), the parameterisation of dry deposition in DAMOS is based on the resistance method. A stomatal compensation point for $\mathrm{NH}_{3}$, and hence a possible bi-directional flux, is not directly included. However, the effect of bi-directional fluxes is indirectly accounted for in the calculations of the Danish ammonia emission inventory, as it takes into account the emission from grown crops due to bi-directional fluxes (Gyldenkærne et al, 2005). The deposition velocity is not affected by this emission.

bi-directional flux can also take place over marine areas, where a previous preliminary study points towards a redistribution of the deposition in the coastal area, and this redistribution tends to reduce the gradients in $\mathrm{NH}_{3}$ deposition (Sorensen et al., 2003). Recent studies with the regional CTM model LOTOS-EUROS include a new flux parameterisation accounting for bi-directional flux in both terrestrial and marine areas and confirm these findings (Van Zanten et al., 2010; Wichink Kruit et al., 2010; Wichink Kruit et al., 2012). The DAMOS system is currently not taking this into account for marine areas.

In general, the descriptions of bi-directional flux have mainly been used at field scale, and input parameters (e.g. stomatal compensation points for various canopy types) needed for more general use, at for example the regional scale, have not been available (Massad et al., 2010; Zhang et al., 2010). Recently, more generalised parameterisations have been proposed (e.g. Wichink Kruit et al., 2010) and we are currently working on an updated version of the DAMOS system, where parts of the parameterisation developed by Massad et al. (2010) will be included to more explicitly account for the bi-directional flux of $\mathrm{NH}_{3}$ over terrestrial ecosystems.

In this study, we have only validated the model system against concentrations of ammonia. So far, only very few data on deposition rates appropriate for model validation are available, as measuring dry deposition of ammonia is very complex and uncertain (Flechard et al., 2011; Hertel et al., 2011). One way to test if the models included in DAMOS cover the important process for ammonia deposition is to compare the model results with the results of other models. The OML-DEP has been a part of an inter-comparison exercise with other local-scale models (ADMS 4, AERMOD, LADD and OPS-st) against measured concentrations around a pig farm and performed the best (Theobald et al., 2009).

The current validation at Danish sites shows a general overestimation by the DEHM model and the coupled system. The reason for this is not yet fully explored. In general, the modelling of ammonia will be affected by uncertainties connected to the emission, the subsequent transport and conversion in the atmosphere as well as to the removal processes. In the following, we discuss the possible reasons for the seen overestimation and the main uncertainties related to the involved processes:

- an overestimation of the national ammonia emissions. As described in Sect. 2.2, the inventory for Denmark is based on a number of detailed activity data and highest 


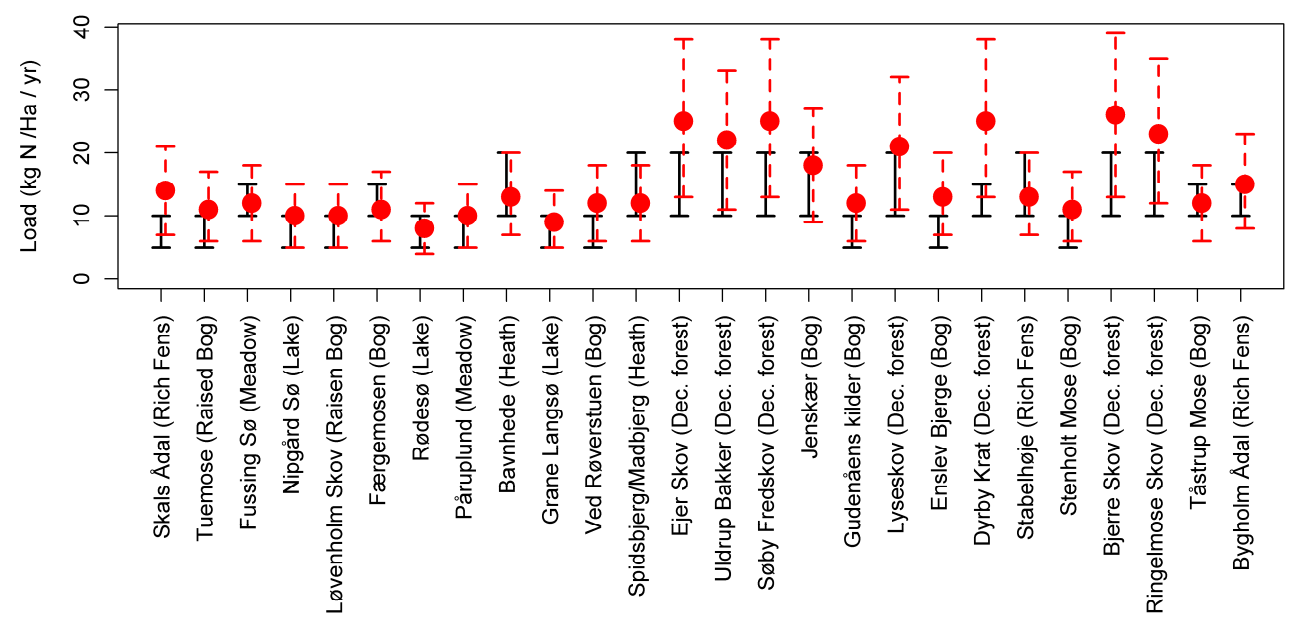

Fig. 9. The estimated $\mathrm{N}$ load with uncertainty interval (in red) to specific nature areas in the Aarhus region in Denmark, displayed in relation to the critical load levels corresponding to the dominating nature types.

uncertainty is assumed to be connected to the applied emission factors. A recent study indicates that the emission from agricultural fields might be overestimated in current inventories, but also concludes that new systematic measuring campaigns are needed in order to lower the uncertainty (Sintermann et al., 2011).

- in the regional model, the spatial averaging of emissions leads to an overestimation of concentrations in high emission areas. It is possible that even the $400 \mathrm{~m} \times 400 \mathrm{~m}$ resolution in the local-scale model at some sites will lead to a too high impact of nearby sources. A newer version of the model will hopefully be able to run with a higher resolution $(100 \mathrm{~m} \times 100 \mathrm{~m})$ and the same domain size of $16 \mathrm{~km} \times 16 \mathrm{~km}$. Thereby, the impact by local emissions can be handled more realistically in the model.

- the parameterisation of the emission does not reflect the true diurnal cycle, but overestimates the nighttime emission, which, combined with typical limited nighttime atmospheric mixing, leads to higher concentrations of ammonia near the surface. The temporal variation of the emission is currently driven by the air temperature at $2 \mathrm{~m}$ (Skjøth et al., 2004) as provided by the meteorological model. In reality, the emission is most likely driven by the surface temperature, which especially during nighttime will be lower than the applied temperature at $2 \mathrm{~m}$ above the surface. Hence, the true emissions will be lower during night than estimated by this parameterization.

- a potential underestimation of the chemical conversion from ammonia to ammonium in DEHM, which is directly linked to the content of acid components in the ambient air and the parameterisation of the exchange between gas phase and aerosol component. When looking at the other nitrogen components simulated by DEHM, it is for example seen that the results show a tendency for underestimating the ammonium concentrations at the Danish sites, while the sum of $\mathrm{NH}_{3}$ and $\mathrm{NH}_{4}$ $\left(\mathrm{NH}_{\mathrm{x}}\right)$ is well captured (Ellermann et al., 2010). This is likely linked to a general underestimation of sulphate in the model. In OML-DEP, the conversion from $\mathrm{NH}_{3}$ to $\mathrm{NH}_{4}$ is probably too large as it is based on the acidity level in the 1980s. The acidity level has decreased significantly since then. However, this will only have a minor effect on the ammonia level in the OML-DEP model.

- an underestimation of the vertical dispersion leading to overestimation of the concentrations close to the source.

- the background concentration used as input on the boundaries of the local-scale model is an average for the full boundary layer in DEHM. This means that, in agricultural/emission areas, the concentration near the surface is underestimated close to the borders of the localscale model compared to real concentrations. Thereby, the deposition of $\mathrm{NH}_{3}$ also will be underestimated near the border and too much $\mathrm{NH}_{3}$ is transported across the domain contributing to an overestimation of the concentration at the measurement sites. We are currently working on a modified version of the local-scale model OML-DEP, where the background concentration from DEHM is included as a profile instead of an average for the full boundary layer in DEHM.

- in general, parameterizations of dry deposition of ammonia are regarded as highly uncertain (Simpson et al., 2011) as they are based on very few field flux data and the involved exchange processes are poorly understood 
(Flechard et al., 2011). In this recent study by Flechard et al., inferential modelling with four different dry deposition modules showed large differences (up to a factor of 3 ) in estimated dry deposition velocities among the models. The main difference is related to how the nonstomatal resistance is described in the models. Only one of the inferential models included a non-zero compensation point for e.g. croplands (leading to a negative deposition velocity here), but otherwise the deposition module from the EMEP model gave the lowest deposition velocities (Flechard et al., 2011). As the description of the dry deposition in the DEHM and OML-DEP is very similar to the module in the EMEP model, this indicates that the modelled deposition in our study lies in the low range of such estimates. A possible underestimation of the deposition could hence be part of the explanation for an overestimation of the ammonia concentration at the Danish sites.

- the omission of a full description of bi-directional fluxes (as discussed in a section above) over land and marine areas adds to the overall uncertainty related to the dry deposition process in DAMOS. As discussed in e.g. Zhang et al. (2010), the inclusion of a dry deposition module with a description of the bi-directional exchange will lead to lower depositions, especially in canopies with high N status. Wichink Kruit (2012) found an increase in the ammonia concentration nearly everywhere across Europe (especially over agricultural fields), when including the bi-directional exchange in a CTM. For our simulations, this indicates that the models possibly overestimate the deposition over agricultural surfaces, leading to a too fast decrease in the atmospheric concentration and hence a too small transport of ammonia to more remote areas. However, part of this is indirectly accounted for as the Danish ammonia emission inventory already includes an emission from grown crops.

- the models do not take an increased deposition at the edges of woods into account. Up to fourfold increases in atmospheric deposition at the forest edges have been reported (De Schrijver et al., 2007). Increased dry deposition seems to be the reason for this so-called edge effect, which can continue up to distances of 50-150 m within the forest (Spangenberg and Kolling, 2004). Omission of this in grid cells with forest might lead to an underestimation of the deposition and hence an overestimation of the concentration.

\section{Applications of the system}

The DAMOS system is applied on a yearly basis at a number (currently more than 100) of selected nature areas as part of the Danish Background Air Quality Monitoring Program.
The system has also been included in assessments carried out for a few environment centres in Denmark as the basis for their management of the Danish NATURA 2000 locations. As part of the Danish implementation of the Habitat and Bird Directives, a management plan for each of the ca. 250 NATURA 2000 sites has been made (Dinesen and Bjerregaard, 2011). For such assessments, the system is used to map the $\mathrm{N}$ deposition to selected nature areas, estimate impact of local vs. non-local emissions and to compare the local N load with critical load values (Frohn et al., 2008; Frohn et al., 2010; Geels et al., 2008; Hertel et al., 2012). The centres have access to maps similar to the maps in Fig. $2 \mathrm{c}$ and $2 \mathrm{~d}$ in order to make priorities for future regulations and actions in order to protect specific nature areas. The total $\mathrm{N}$ load is estimated as the sum of $\mathrm{NH}_{3}$ deposition from DAMOS and wet deposition (of $\mathrm{NH}_{3}, \mathrm{NH}_{4}$ and $\mathrm{NO}_{3}$ ) and dry deposition of $\mathrm{NH}_{4}$ and $\mathrm{NO}_{3}$ as extracted from the regional model. Based on experience from the Danish Background Air Quality Monitoring Program where measured and modelled nitrogen components at the five main Danish stations are analysed each year, we approximate the uncertainty related to the annual total nitrogen deposition to land areas to be on the order of $+/-40 \%$ for DEHM and up to $+/-50 \%$ for the coupled system DAMOS (Ellermann et al., 2011). This is the uncertainty for the mean over grid cells, but in the absolute vicinity of large point sources, such as large farms, the uncertainty can exceed $50 \%$ in the $400 \mathrm{~m} \times 400 \mathrm{~m}$ fields from DAMOS. This is due to the fact that that the gradients and changes that are present within the first $400 \mathrm{~m}$ of the big point sources are substantial and the algorithms used in the local-scale model OML-DEP have not been validated for such potentially very high deposition values. In Fig. 9, the simulated total nitrogen loads at 26 specific nature areas in the Aarhus region in Denmark are displayed together with the critical loads related to the general nature types within each nature area. The critical load is given as an interval, and the simulated values are shown as a central estimate with an uncertainty interval of $+/-50 \%$. The central estimate is at 13 areas seen to be above the upper limit of the critical load and for nine of these sites the DAMOS results based on different scenarios showed that it is not possible to get below this upper limit even if the local sources are reduced. At none of the sites the central estimate of the $\mathrm{N}$ deposition was below the critical load, but at 13 sites the lower end of the uncertainty interval is equal to or below the lower limit of the critical load. These assessments have been described in more detail in Hertel et al. (2012). The described assessments are based on model simulations for a specific year. However, the current analysis of the inter-annual variations (Sect. 3.2.1) shows that year-toyear variation in the meteorology alone can lead to variations in the annual nitrogen load on the order of approximately 10 $20 \%$. These variations are well below the overall uncertainty of such estimates, but should, if possible, be taken into account when the estimated nitrogen loads are used for management. Alternatively, the estimated nitrogen load should 
Table 5. An example of the modelled annual deposition (dry and wet) of $\mathrm{NH}_{\mathrm{x}}$ and $\mathrm{NO}_{\mathrm{y}}$ to a coniferous forest in Denmark. The first row presents the deposition estimated by the DAMOS system. The next four rows show the estimates from the DEHM model alone, in the $5.56 \mathrm{~km}$ grid and $50 \mathrm{~km}$ grid, respectively. The DEHM results are extracted for a coniferous forest or as mean over all land-use types in the specific grid cell. Note that the differences between the numbers to the forest and the mean for the grid will depend on e.g. the relative occurrence of different land-use types in the specific grid cell.

\begin{tabular}{|c|c|c|c|c|c|}
\hline & Dry $\mathrm{NH}_{\mathrm{x}}$ & Dry $\mathrm{NO}_{\mathrm{y}}$ & Wet $\mathrm{NH}_{\mathrm{x}}$ & Wet $\mathrm{NO}_{\mathrm{y}}$ & Total N dep \\
\hline & $\mathrm{kgNha}^{-1} \mathrm{yr}^{-1}$ & $\mathrm{~kg} \mathrm{Nha}^{-1} \mathrm{yr}^{-1}$ & $\mathrm{~kg} \mathrm{Nha}^{-1} \mathrm{yr}^{-1}$ & $\mathrm{~kg} \mathrm{Nha}^{-1} \mathrm{yr}^{-1}$ & $\mathrm{~kg} \mathrm{Nha}^{-1} \mathrm{yr}^{-1}$ \\
\hline DAMOS to con. forest & 6.3 & 7.3 & 4.2 & 3.8 & 21.5 \\
\hline DEHM (5.56 km grid) to con. forest & 13.8 & 7.3 & 4.2 & 3.8 & 29.0 \\
\hline DEHM (5.56 km grid) to mean grid & 6.0 & 3.0 & 4.2 & 3.8 & 17.0 \\
\hline DEHM (50 km grid) to con. forest & 16.4 & 6.7 & 4.2 & 3.8 & 31.0 \\
\hline DEHM (50 km grid) to mean grid & 5.6 & 1.8 & 4.2 & 3.8 & 15.4 \\
\hline
\end{tabular}

be based on model simulations covering several years, e.g. in order to avoid the impact of a single extreme year.

The model results are extracted for the land-use category corresponding to the specific nature areas, which, combined with the higher resolution in the DAMOS system, gives a more precise estimate of the total $\mathrm{N}$ load. In order to illustrate this, the central estimate of the total $\mathrm{N}$ load at a specific coniferous forest as extracted from DAMOS and two different nests of the DEHM model (50 km grid and $5.56 \mathrm{~km}$ grid) is shown as an example in Table 5. The total $\mathrm{N}$ load would in the DAMOS system be estimated at about $22 \mathrm{~kg} \mathrm{Nha}^{-1}$ at this forest site. The regional model estimated a load of ca. $29 \mathrm{~kg} \mathrm{Nha}^{-1}$ in the $5.56 \mathrm{~km}$ grid and ca. $31 \mathrm{~kg} \mathrm{Nha}^{-1}$ in the $50 \mathrm{~km}$ grid. If the load is based on an average over all the nature types within the $5.56 \mathrm{~km} \times 5.56 \mathrm{~km}$ (or $50 \mathrm{~km} \times 50 \mathrm{~km}$ ) grid cell including the specific coniferous forest, it would be ca. $17 \mathrm{~kg} \mathrm{Nha}^{-1}$ (or $15 \mathrm{~kg} \mathrm{Nha}^{-1}$ ). The contribution from wet deposition of $\mathrm{NH}_{\mathrm{x}}$ and $\mathrm{NO}_{\mathrm{y}}$ (also given in Table 5) is not dependent on the land-use type; however, differences are seen for the calculated dry deposition. When extracting dry deposition to the forest, the regional model alone gives a very high estimate for $\mathrm{NH}_{3}$. Highest total load is obtained from the $50 \mathrm{~km}$ grid in DEHM. This is in line with Dore et al. (2012), who found greater area exceedance with coarser grid resolution in the UK. This is mainly because the heterogeneity in the emissions is not resolved in the coarser grid. When averaging over all the land-use types in the grid cell $(5.56 \mathrm{~km} \times 5.56 \mathrm{~km}$ or $50 \mathrm{~km} \times 50 \mathrm{~km})$, lower values of dry deposited $\mathrm{NH}_{\mathrm{x}}$ as well as $\mathrm{NO}_{\mathrm{y}}$ are obtained. Such average estimates for grid cells will be very dependent on the specific sharing of land-use types within the cell. In this example, the mean load from the $50 \mathrm{~km}$ grid is ca. $15 \mathrm{~kg} \mathrm{~N} \mathrm{ha}^{-1}$ as the part covered by forest is small compared to other land-use types. This type of estimate will hence not be very representative for explicit nature types.

This example emphasizes the importance of using a model system that covers both local to regional scale as well as a system that includes deposition to different land-use types of both $\mathrm{NH}_{3}$ and the other nitrogen components. Even in an agricultural country like Denmark, the other nitrogen com- ponents contribute significantly to the total $\mathrm{N}$ load at a given site.

\section{Summary and conclusions}

The main goal of this research has been to develop a coupled model system in order to improve the modelling of atmospheric ammonia in a landscape with a mix of agricultural and natural/semi-natural areas. The model system has been validated against measured $\mathrm{NH}_{3}$ concentrations from 21 sites in Denmark. Our findings that are summarized in the following can be used to bring environmental management a step forward:

- The results show that the regional model DEHM overestimates observed local ammonia concentrations across Denmark due to the fact that local agricultural emissions are distributed over grid cells of $5.56 \mathrm{~km} \times 5.56 \mathrm{~km}$.

- Coupling the regional model DEHM with the localscale model OML-DEP, as it is done in DAMOS, improves the results.

- A detailed spatial and temporal description of $\mathrm{NH}_{3}$ emissions is crucial for the improved modelling of ammonia also at the intra-annual timescales.

- Detailed land-use information is also important for precise estimates of the deposition to specific nature areas.

- The fraction of locally emitted $\mathrm{NH}_{3}$ depositing locally (here in a $16 \mathrm{~km} \times 16 \mathrm{~km}$ domain) is on the order of $15 \%$ to $30 \%$.

- For Danish areas, the $\mathrm{NH}_{3}$ contributions from non-local $\mathrm{NH}_{3}$ sources are on the order of $50 \%$. However, when including wet deposition and dry deposition of other $\mathrm{N}$ components, the non-local sources dominate the local deposition and in total exceed the critical loads of many sensitive ecosystems. The local contributions are hence often moderate. 
- A background concentration reflecting the non-local emissions within the region of a specific area is hence important when making assessments of the total nitrogen load. This is obtained with a model system like DAMOS where models covering both the regional to local scale are applied in combination with detailed surface information (emissions and land-cover). However, there are still large uncertainties related to modelling of the nitrogen load and these should be taken into account when the model system is used in environmental management.

- A better representation of the surface exchange of ammonia in the next version of DAMOS can potentially reduce the uncertainty. Nevertheless, the surface exchanges of nitrogen components are highly parameterized in current CTMs, and dedicated measurements of both the gas and particle components are needed in order to constrain the applied model parameters.

Acknowledgements. The present study has been supported by NOVANA - the Nationwide Monitoring and Assessment Programme for the Aquatic and Terrestrial Environments and by the Nordic Council of Ministers.

Edited by: S. Reis

\section{References}

Andersen, H. V. and Hovmand, M. F., Measurements of Ammonia and Ammonium by Denuder and Filter Pack, Atmos. Environ., 28, 3495-3512, 1994.

Andersen, H. V., Løfstrøm, P., Moseholm, L., Ellermann, T., and Nielsen, K. E.: Metodeafprøvning af passive diffusionsopsamlere til koncentrationsbestemmelse af ammoniak (in Danish), National Environmental Research Institute, Aarhus University, DK4000 Roskilde, Denmark, 1-42, 2009.

Asman, W. A. H., Factors influencing local dry deposition of gases with special reference to ammonia, Atmos. Environ., 32, 415421, 1998.

Asman, W. A. H., Pinksterboer, E. F., Maas, H. F. M., Erisman, J. W., Waijersypelaan, A., Slanina, J., and Horst, T. W., Gradients of the Ammonia Concentration in A Nature Reserve - Model Results and Measurements, Atmos. Environ., 23, 2259-2265, 1989.

Bartnicki, J., Semeena, V. S., and Fagerli, H.: Atmospheric deposition of nitrogen to the Baltic Sea in the period 1995-2006, Atmos. Chem. Phys., 11, 10057-10069, doi:10.5194/acp-1110057-2011, 2011.

Bobbink, R., Hicks, K., Galloway, J., Spranger, T., Alkemade, R., Ashmore, M., Bustamante, M., Cinderby, S., Davidson, E., Dentener, F., Emmett, B., Erisman, J. W., Fenn, M., Gilliam, F., Nordin, A., Pardo, L., and de Vries, W.: Global assessment of nitrogen deposition effects on terrestrial plant diversity: a synthesis, Ecol. Appl., 20, 30-59, 2010.
Brandt, J., Christensen, J. H., Frohn, L. M., Palmgren, F., Berkowicz, R., and Zlatev, Z., Operational air pollution forecasts from European to local scale, Atmos. Environ., 35, S91-S98, 2001.

Brandt, J., Silver, J. D, Christensen, J. H., Andersen, M. S., Bønløkke, J. H., Sigsgaard, T., Geels, C., Gross, A., Hansen, A. B., Hansen, K. M., Hedegaard, G. B., Kaas, E., and Frohn, L. M.: Assessment of Health-Cost Externalities of Air Pollution at the National Level using the EVA Model System, CEEH Scientific Report No 3, Centre for Energy, Environment and Health Report series, 1-98, 2011.

Brandt, J., Silver, J., Frohn, L. M., Geels, C., Gross, A., Hansen, A. B., Hansen, K. M., Hedegaard, G. B., Skjøth, C. A., Villadsen, H., Zare, A., and Christensen, J. H.: An integrated model study for Europe and North America using the Danish Eulerian Hemispheric Model withfocus on intercontinental transport of air pollution, Atmos. Environ., 53, 156-176, 2012.

Christensen, J. H., The Danish Eulerian hemispheric model - A three-dimensional air pollution model used for the Arctic, Atmos. Environ., 31, 4169-4191, 1997.

Christensen, J. H., Brandt, J., Frohn, L. M., and Skov, H.: Modelling of Mercury in the Arctic with the Danish Eulerian Hemispheric Model, Atmos. Chem. Phys., 4, 2251-2257, doi:10.5194/acp-42251-2004, 2004.

Conley, D. J., Paerl, H. W., Howarth, R. W., Boesch, D. F., Seitzinger, S. P., Havens, K. E., Lancelot, C., and Likens, G. E., Controlling Eutrophication: Nitrogen and Phosphorus, Science, 323, 1014-1015, 2009.

De Schrijver, A., Devlaeminck, R., Mertens, J., Wuyts, K., Hermy, M., and Verheyen, K.: On the importance of incorporating forest edge deposition for evaluating exceedance of critical pollutant loads, Appl. Veget. Sci., 10, 293-298, 2007.

Dennis, R. L., Mathur, R., Pleim, J. E., and Walker, J. T.: Fate of ammonia emissions at the local to regional scales as simulated by the Community Multiscale Air Quality model, Atmos. Pollut. Res., 1, 207-214, 2010.

Dinesen, L. and Bjerregaard, H., Nitrogen deposition and Nature 2000 in Denmark in: Nitrogen Deposition and Nature 2000: Science \& practice in determining environmental impacts, edited by: Hicks, W. K., Whitfield, C. P., Bealey, W. J., and Sutton, M. A., COST office, 252-256, 2011.

Dore, A. J., Kryza, M., Hall, J. R., Hallsworth, S., Keller, V. J. D., Vieno, M., and Sutton, M. A.: The influence of model grid resolution on estimation of national scale nitrogen deposition and exceedance of critical levels, Biogeosciences Discuss., 8, 12079 12112, doi:10.5194/bgd-8-12079-2011, 2011.

Dragosits, U., Theobald, M. R., Place, C. J., Lord, E., Webb, J., Hill, J., Apsimon, H. M., and Sutton, M. A., Ammonia emission, deposition and impact assessment at the field scale: a case study of sub-grid spatial variability, Environ. Pollut., 117, 147-158, 2002.

Duyzer, J., Nijenhuis, B., and Weststrate, H.: Monitoring and Modelling of Ammonia Concentrations and Deposition in Agricultural Areas of The Netherlands, Water, Air, \& Soil Pollution: Focus, 1, 131-144, 2001.

EEA: Europe's Environment - The Third Assessment, European Environment Agency, Copenhagen, Denmark, 341 p, 2003.

EEA: The European Environment - state and outlook 2010, synthesis European Environment Agency, Copenhagen, Denmark.

Ellermann, T., Andersen, H. A., Bossi, R., Christensen, J. H., Kemp, K., Løfstrøm, P., and Monies, C.: Atmospheric deposition 2008 
NOVANA (In Danish: Atmosfærisk deposition 2008 NOVANA), National Environmental Research Institute, Aarhus University, 1-74, 2009.

Ellermann, T., Andersen, H. A., Bossi, R., Christensen, J. H., Løfstrøm, P., Monies, C., Grundahl, L., and Geels, C.: Atmospheric deposition 2009 NOVANA (In Danish: Atmosfærisk deposition 2009 NOVANA), National Environmental Research Institute, Aarhus University, 1-95, 2010.

Ellermann, T., Andersen, H. A., Bossi, R., Christensen, J. H., Løfstrøm, P., Monies, C., Grundahl, L., and Geels, C.: Atmospheric deposition 2010, NOVANA (Report in Danish: Atmosfærisk deposition 2010 NOVANA), Aarhus Universitet, DCE Nationalt Center for Miljø og Energi., 1-109, 2011.

Emberson, L. D., Ashmore, M. R., Cambridge, H. M., Simpson, D., and Tuovinen, J. P., Modelling stomatal ozone flux across Europe, Environ. Pollut., 109, 403-413, 2000.

Erisman, J. W., Hensen, A., Mosquera, J., Sutton, M., and Fowler, D., Deposition monitoring networks: what monitoring is required to give reasonable estimates of ammonia/ammonium?, Environ. Pollut., 135, 419-431, 2005.

Fagerli, H. and Aas, W., Trends of nitrogen in air and precipitation: Model results and observations at EMEP sites in Europe, 19802003, Environmental Pollution, 154, 448-461, 2008.

Farquhar, G. D., Firth, P. M., Wetselaar, R., and Weir, B., On the Gaseous Exchange of Ammonia Between Leaves and the Environment - Determination of the Ammonia Compensation Point, Plant Physiol., 66, 710-714, 1980.

Ferm, M.: Method for determination of atmospheric ammonia, Atmos. Environ., 13, 1385-1393, 1979.

Ferm, M.: Atmospheric ammonia and ammonium transport in Europe and critical loads: a review, Nutrient Cycling in Agroecosystems, 51, 5-17, 1998.

Flechard, C. R., Nemitz, E., Smith, R. I., Fowler, D., Vermeulen, A. T., Bleeker, A., Erisman, J. W., Simpson, D., Zhang, L., Tang, Y. S., and Sutton, M. A.: Dry deposition of reactive nitrogen to European ecosystems: a comparison of inferential models across the NitroEurope network, Atmos. Chem. Phys., 11, 2703-2728, doi:10.5194/acp-11-2703-2011, 2011.

Forsius, M., Posch, M., Aherne, J., Reinds, G. J., Christensen, J., and Hole, L.: Assessing the Impacts of Long-Range Sulfur and Nitrogen Deposition on Arctic and Sub-Arctic Ecosystems, Ambio, 39, 136-147, 2010.

Fournier, N., Pais, V. A., Sutton, M. A., Weston, K. J., Dragosits, U., Tang, S. Y., and Aherne, J.: Parallelisation and application of a multi-layer atmospheric transport model to quantify dispersion and deposition of ammonia over the British Isles, Environ. Pollut., 116, 95-107, 2002.

Fowler, D., Pitcairn, C. E. R., Sutton, M. A., Flechard, C., Loubet, B., Coyle, M., and Munro, R.: The mass budget of atmospheric ammoina in woodland within $1 \mathrm{~km}$ of lifestock buildings, Environ Pollut, 102, 343-348, 1998.

Frohn, L. M., Christensen, J. H., and Brandt, J.: Development of a high-resolution nested air pollution model - The numerical approach, J. Comput. Phys., 179, 68-94, 2002.

Frohn, L. M., Geels, C., Madsen, P. V., and Hertel, O.: Nitrogen load of nature areas in Eastern Jutland (In Danish: Kvælstofbelastning af naturområder i Østjylland), Nat. Environ. Res. Inst., University of Aarhus, 2008.
Frohn, L. M., Skjøth, C. A., Becker, T., Geels, C., and Hertel, O.: Nitrogen load at selected terrestrial habitant areas in Sønderborg Municipality (In Danish: Kvælstofbelastning ved udvalgte terrestriske habitatområder i Sønderborg Kommune), Nat. Environ. Res. Inst., University of Aarhus, 2010.

Geels, C., Doney, S. C., Dargaville, R., Brandt, J., and Christensen, J. H.: Investigating the sources of synoptic variability in atmospheric $\mathrm{CO}_{2}$ measurements over the Northern Hemisphere continents: a regional model study, Tellus B, 56, 35-50, 2004.

Geels, C., Brandt, J., Christensen, J., Frohn, L., and Hansen, K.: Long-Term Calculations with a Comprehensive Nested Hemispheric Air Pollution Transport Model, edited by: Faragó, I., Georgiev, K., and Havasi, Á., Springer Netherlands, 185-196, 2005.

Geels, C., Frohn, L. M., Madsen, P. V., and Hertel, O.: Nitrogen loads of nature areas on Bornholm and Sealand (In Danish: Kvælstofbelastning af naturområder på Bornholm og Sjælland), National Environmental Research Institute, University of Aarhus., 2008.

Geels, C., Gloor, M., Ciais, P., Bousquet, P., Peylin, P., Vermeulen, A. T., Dargaville, R., Aalto, T., Brandt, J., Christensen, J. H., Frohn, L. M., Haszpra, L., Karstens, U., Rödenbeck, C., Ramonet, M., Carboni, G., and Santaguida, R.: Comparing atmospheric transport models for future regional inversions over Europe - Part 1: mapping the atmospheric $\mathrm{CO}_{2}$ signals, Atmos. Chem. Phys., 7, 3461-3479, doi:10.5194/acp-7-3461-2007, 2007.

Geels, C., Hansen, K. M., Christensen, J. H., Ambelas Skjøth, C., Ellermann, T., Hedegaard, G. B., Hertel, O., Frohn, L. M., Gross, A., and Brandt, J.: Projected change in atmospheric nitrogen deposition to the Baltic Sea towards 2020, Atmos. Chem. Phys., 12, 2615-2629, doi:10.5194/acp-12-2615-2012, 2012.

Genualdi, S., Harner, T., Cheng, Y., MacLeod, M., Hansen, K. M., van Egmond, R., Shoeib, M., and Lee, S. C., Global Distribution of Linear and Cyclic Volatile Methyl Siloxanes in Air, Environ. Sci. Technol., 45, 3349-3354, 2011.

Graedel, T. F., Bates, T. S., Bouman, A. F., Cunnold, D., Dignon, J., Fung, I., Jacob, D. J., Lamb, B. K., Logan, J. A., Marland, G., Middleton, P., Pacyna, J. M., Placet, M., and Veldt, C.: A compilation of inventories of emissions to the atmosphere, Global Bio. Chem. Cycl., 7, 1-16, 1993.

Grell, G. A., Dudhia, J., and Stauffer, D. R.: A description of the fifth-generation Penn State NCAR Mesoscale Model (MM5), Mesoscale and Microscale Meteorology Division, Nat. Center Atmos. Res., Boulder, Colorado, 122, 1-22, 1995.

Gyldenkærne, S., Ambelas Skjøth, C., Hertel, O., and Ellermann, T.: A dynamical ammonia emission parameterization for use in air pollution models, J. Geophys. Res., 110, D07108, doi:10.1029/2004JD005459, 2005.

Hallsworth, S., Dore, A. J., Bealey, W. J., Dragosits, U., Vieno, M., Hellsten, S., Tang, Y. S., and Sutton, M. A.: The role of indicator choice in quantifying the threat of atmospheric ammonia to the "Natura 2000" network, Environ. Sci. Pol., 13, 671-687, 2010.

Hansen, K. M., Halsall, C. J., Christensen, J. H., Brandt, J., Frohn, L. M., Geels, C., and Skjøth, C. A.: The role of the snowpack on the fate of alpha- $\mathrm{HCH}$ in an atmospheric chemistry-transport model, Environ. Sci. Technol., 42, 2943-2948, 2008.

Hedegaard, G. B., Brandt, J., Christensen, J. H., Frohn, L. M., Geels, C., Hansen, K. M., and Stendel, M.: Impacts of climate 
change on air pollution levels in the Northern Hemisphere with special focus on Europe and the Arctic, Atmos. Chem. Phys., 8, 3337-3367, doi:10.5194/acp-8-3337-2008, 2008.

Hedegaard, G. B., Gross, A., Christensen, J. H., May, W., Skov, H., Geels, C., Hansen, K. M., and Brandt, J., Modelling the impacts of climate change on tropospheric ozone over three centuries, Atmos. Chem. Phys. Discuss., 11, 6805-6843, 2011, http://www.atmos-chem-phys-discuss.net/11/6805/2011/.

Hertel, O., Ambelas Skjøth, C., Brandt, J., Christensen, J. H., Frohn, L. M., and Frydendall, J.: Operational mapping of atmospheric nitrogen deposition to the Baltic Sea, Atmos. Chem. Phys., 3, 2083-2099, doi:10.5194/acp-3-2083-2003, 2003.

Hertel, O., Skjøth, C. A., Lofstrom, P., Geels, C., Frohn, L. M., Ellermann, T., and Madsen, P. V.: Modelling nitrogen deposition on a local scale - A review of the current state of the art, Environ. Chem., 3, 317-337, 2006.

Hertel, O., Ellermann, T., Palmgren, F., Berkowicz, R., Lofstrom, P., Frohn, L. M., Geels, C., Skjøth, C. A., Brandt, J., Christensen, J., Kemp, K., and Ketzel, M., Integrated air-quality monitoring combined use of measurements and models in monitoring programmes, Environ. Chem., 4, 65-74, 2007.

Hertel, O., Reis, S., Skjøth, C. A., Bleeker, A., Harrison, R., Cape, J. N., Fowler, D., Skiba, U., Simpson, D., Jickells, T., Baker, A., Kulmala, M., Gyldenkærne, S., Sørensen, L. L., and Erisman, J. W., Nitrogen processes in the atmosphere in: The European Nitrogen Assessment, edited by: Sutton, M., Howard, C. M., Erisman, J. W., Billen, G., Bleeker, A., Grennfelt, P., Grinsven, H., and Grizzetti, B., Cambridge, 177-207, 2011.

Hertel, O., Geels, C., Frohn, L. M., Ellermann, T., Skjøth, C. A., Løfstrøm, P., Christensen, J. H., Andersen, H. A., and Peel, R. G.: Assessing atmospheric nitrogen deposition to natural and semi-natural ecosystems - experience from Danish studies using the DAMOS system, Atmos. Environ., http://dx.doi.org/10. 1016/j.atmosenv.2012.02.071, 2012.

Jensen, S. S., Brandt, J., Frohn, L. M., Winther, M., Nielsen, O.K., Jørgensen, K., and Karlsson, K.: Impacts of large-scale introduction of hydrogen in the road transport sector on urban air pollution and human exposure in Copenhagen in International Conference on Energy, Environment and Health, - Optimisation of Future Energy Systems, 2011.

Krupa, S. V., Effects of atmospheric ammonia $\left(\mathrm{NH}_{3}\right)$ on terrestrial vegetation: a review, Environ. Pollut., 124, 179-221, 2003.

Kryza, M., Dore, A. J., Blas, M., and Sobik, M.: Modelling deposition and air concentration of reduced nitrogen in Poland and sensitivity to variability in annual meteorology, J. Environ. Manage., 92, 1225-1236, 2011.

Lamarque, J.-F., Bond, T. C., Eyring, V., Granier, C., Heil, A., Klimont, Z., Lee, D., Liousse, C., Mieville, A., Owen, B., Schultz, M. G., Shindell, D., Smith, S. J., Stehfest, E., Van Aardenne, J., Cooper, O. R., Kainuma, M., Mahowald, N., McConnell, J. R., Naik, V., Riahi, K., and van Vuuren, D. P.: Historical (1850-2000) gridded anthropogenic and biomass burning emissions of reactive gases and aerosols: methodology and application, Atmos. Chem. Phys., 10, 7017-7039, doi:10.5194/acp10-7017-2010, 2010.

Langner, J., Andersson, C., and Engardt, M.: Atmospheric input of nitrogen to the Baltic Sea basin: present situation, variability due to meteorology and impact of climate change, Boreal Environ. Res., 14, 226-237, 2009.
Langner, J., Engardt, M., Baklanov, A., Christensen, J. H., Gauss, M., Geels, C., Hedegaard, G. B., Nuterman, R., Simpson, D., Soares, J., Sofiev, M., Wind, P., Zakey, A.: A multi-model study of impacts of climate change on surface ozone in Europe, Atmos. Chem. Phys. Discuss. 12, 4901-4939, 2012.

Loubet, B., Milford, C., Sutton, M. A., and Cellier, P., Investigation of the interaction between sources and sinks of atmospheric ammonia in an upland landscape using a simplified dispersionexchange model, J. Geophys. Res-Atmos., 106, 24183-24195, 2001.

Loubet, B., Asman, W. A. H., Theobald, M. R., Hertel, O., Tang, Y. S., Robin, P., Hassouna, M., Dämmgen, U., Genermont, S., Cellier, P., and Sutton, M.: Ammonia Deposition Near Hot Spots: Processes, models and Monitoring Methods in: Atmospheric Ammonia Detecting emission changes and environmental impacts. Results of an Expert Workshop under the Convention on Long-range Transboundary Air Pollution, edited by: Sutton, M., Reis, S., and Baker, S. M. H., Springer Since and Business Media B.V., 205-268, 2009.

Mareckova, K., Wankemuller, R., Anderl, M., Muik, B, Poupa, S., and Wieser, M: Inventory review 2008: Emission data reported under the LRTAP convention and NEC directive, Status of gridded data, 2008.

Massad, R.-S., Nemitz, E., and Sutton, M. A.: Review and parameterisation of bi-directional ammonia exchange between vegetation and the atmosphere, Atmos. Chem. Phys., 10, 10359-10386, doi:10.5194/acp-10-10359-2010, 2010.

Menut, L. and Bessagnet, B.: Atmospheric composition forecasting in Europe, Ann. Geophys., 28, 61-74, doi:10.5194/angeo-28-612010, 2010.

Nemitz, E. and Sutton, M. A.: Gas-particle interactions above a Dutch heathland: III. Modelling the influence of the $\mathrm{NH}_{3}-\mathrm{HNO}_{3}$ $\mathrm{NH}_{4} \mathrm{NO}_{3}$ equilibrium on size-segregated particle fluxes, Atmos. Chem. Phys., 4, 1025-1045, doi:10.5194/acp-4-1025-2004, 2004.

Nemitz, E., Sutton, M. A., Wyers, G. P., and Jongejan, P. A. C.: Gas-particle interactions above a Dutch heathland: I. Surface exchange fluxes of $\mathrm{NH}_{3}, \mathrm{SO}_{2}, \mathrm{HNO}_{3}$ and $\mathrm{HCl}$, Atmos. Chem. Phys., 4, 989-1005, doi:10.5194/acp-4-989-2004, 2004.

Nielsen, K., Stjernholm, M, Østergaard Olsen, B., Müller-Wohlfeil, D.-I., Madsen, I., Kjeldgaard, A., Groom, G., Hansen, H. S., Rolev, A. M., Hermansen, B., Skov-Petersen, H., Johannsen, V. K., Hvidberg, M., Jensen, J. E., Bacher, V., and Larsen, H.: Areal Informations Systemet - AIS (In Danish), Miljø- og Energiministeriet, Danmarks Miljøundersøgelser, 2000.

Nielsen, O.-K., Winther, M., Mikkelsen, M. H., Hoffmann, L., Nielsen, M., Gyldenkærne, S., Fauser, P., Plejdrup, M. S., Albrektsen, R., Hjelgaard, K., and Bruun, H. G: Annual Danish Informative Inventory Report to UNECE. Emission inventories from the base year of the protocols to year 2009, Nat. Environ. Res. Inst., Aarhus University., 1-601, 2011.

Olesen, H. R., Løfstrøm, P., Berkowicz, R., and Jensen, A. B.: An Improved Dispersion Model for Regulatory Use - The OML Model, edited by: Dop, H. and Kallos, G., Plenum Press, 1992.

Olesen, H. R., Winther, M., Ellermann, T., Christensen, J. H., and Plejdrup, M. S.: Ship emissions and air pollution in Denmark: Present situation and future scenarios, The Danish Environmental Protection Agency, 2009. 
Pitcairn, C. E. R., Skiba, U. M., Sutton, M. A., Fowler, D., Munro, R., and Kennedy, V., Defining the spatial impacts of poultry farm ammonia emissions on species composition of adjacent woodland groundflora using Ellenberg Nitrogen Index, nitrous oxide and nitric oxide emissions and foliar nitrogen as marker variables, Environ. Pollut., 119, 9-21, 2002.

Plejdrup, M. S. and Gyldenkærne, S.: Spatial distribution of emissions to air - the SPREAD model, National Environmental Research Institute, Aarhus University., 1-72, 2011.

Poulsen, H. D: Annual updates of nitrogen excretion rates can be found at: http://www.agrsci.dk/ny\{_\}navigation/ institutter/institut \{_\}for\{_\}husdyrbiologi\{_\}og \{_\}sundhed/ husdyrernaering \{_\}og\{_\}miljoe/normtal , 1-33, 2011.

Poulsen, H. D., Børsting, C. F., Rom, H. B., and Sommer, S. G.: Kvælstof, fosfor og kalium i husdyrgødning - normtal 2000, 2001.

Pul, A. v., Jaarsveld, H. V., Meulen, T. v. d., and Velders, G.: Ammonia concentrations in the Netherlands: spatially detailed measurements and model calculations, Atmos. Environ., 38, 4045-4055, 2004.

Pul, A. v., Hertel, O., Geels, C., Dore, A. J., Vieno, M., Jaarsveld, H. A. v., Bergström, R., Schapp, M., and Fagerli, H., Modelling the Atmospheric Transport and Deposition of Ammonia at a National and regional Scale in: Atmospheric Ammonia; Detecting emission changes and environmental impacts, edited by: Sutton, M. A., Reis, S., and Baker, S. M. H., Springer, 464 p., 2009a.

Pul, A. V., Reis, S., Dore, A. J., Xuejun, L., Fagerli, H., Geels, C., Hertel, O., Wichink-Kruit, R., Kryza, M., Bergström, R., Vieno, M., Smith, R., and Nemitz, E.: Modelling the National and regional Transport and Deposition of Ammonia in: Atmospheric Ammonia; Detecting emission changes and environmental impacts, edited by: Sutton, M. A., Reis, S., and Baker, S. M. H., Springer, 409-421, 2009b.

Reis, S., Skjøth, C. A., Vieno, M., Geels, C., Dragosits, U., Tang, S. Y., Twigg, M., Smith, R. I., and Sutton, M.: Improving temporal profiles of argicultural ammonia emissions for atmospheric modelling, Biogeosciences, in prep., 2012.

Schou, J. S., Tybirk, K., Løfstrøm, P., and Hertel, O.: Economic and environmental analysis of buffer zones as an instrument to reduce ammonia loads to nature areas, Land Use Policy, 23, 533-541, 2006.

Schultz, M. G., Heil, A., Hoelzemann, J. J., Spessa, A., Thonicke, K., Goldammer, J. G., Held, A. C., Pereira, J. M. C., and van het Bolscher, M.: Global wildland fire emissions from 1960 to 2000, Global Bio. Chem. Cycl., 22, 1-17, 2008.

Sheppard, L. J., Leith, I. D., Crossley, A., Dijk, N. v., Cape, N. J., Fowler, D., and Sutton, M., Long-term cumulative exposure exacerbates the effects of atmospheric ammonia on an Ombrotrophic Bog: implications for Critical Levels in: Atmospheric Ammonia. Detecting emission changes and environmental impacts, edited by: Sutton, M., Reis, S., and Baker, S. M. H., Springer, 49-58, 2009.

Simpson, D., Aas, W., Bartnicki, J., Berge, H., Bleeker, A., Cuvelier, C., Dentener, F., Dore, T., Erisman, J. W., Fagerli, H., Flechard, C., Hertel, O., Van Jaarsveld, H., Jenkin, M. E., Schaap, M., Smeena, V. S., Thunis, P., Vautard, R., and Vieno, M., Chapter 14: Atmospheric transport and deposition of reactive nitrogen in Europe in: The European Nitrogen Assessment Sources, Effects and Policy Perspectives, edited by: Sutton, M.,
Howard, C. M., Erisman, J. W., Billen, G., Bleeker, A., Grennfelt, P., van Grinsven, H., and Grizzetti, B., Cambridge University Press, Cambridge, UK, 298-316, 2011.

Simpson, D., Fagerli, H., Jonson, J. E., Tsyro, S., Wind, P., and Tuovinen J.-P.: Transboundary Acidification, Eutrophication and Ground Level Ozone in Europe, PART I, Unified EMEP Model Description, 1-104, 1-8-2003.

Sintermann, J., Neftel, A., Ammann, C., Häni, C., Hensen, A., Loubet, B., and Flechard, C. R.: Are ammonia emissions from fieldapplied slurry substantially over-estimated in European emission inventories?, Biogeosciences Discuss., 8, 10069-10118, doi:10.5194/bgd-8-10069-2011, 2011.

Skjøth, C. A., Hertel, O., Gyldenkærne, S., and Ellermann, T.: Implementing a dynamical ammonia emission parameterization in the large-scale air pollution model ACDEP, J. Geophys. Res., 109, D06306, doi:10.1029/2003JD003895, 2004.

Skjøth, C. A., Ellermann, T., Hertel, O., Gyldenkærne, S., and Mikkelsen, M. H.: Footprints on ammonia concentrations from environmental regulations, J. Ait Waste Manage., 58, 11581165, 2008.

Skjøth, C. A., Geels, C., Berge, H., Gyldenkærne, S., Fagerli, H., Ellermann, T., Frohn, L. M., Christensen, J., Hansen, K. M., Hansen, K., and Hertel, O.: Spatial and temporal variations in ammonia emissions - a freely accessible model code for Europe, Atmos. Chem. Phys., 11, 5221-5236, doi:10.5194/acp-11-52212011, 2011.

Sommer, S. G. and Jensen, E. S.: Foliar Absorption of Atmospheric Ammonia by Ryegrass in the Field, J. Environ. Qual., 20, 153$156,1991$.

Sommer, S. G., Østergård, H. S., Løfstrøm, P., Andersen, H. V., and Jensen, L. S.: Validation of model calculation of ammonia deposition in the neighbourhood of a poultry farm using measured NH3 concentrations and N deposition, Atmos. Environ., 43, 915920, 2009.

Spangenberg, A. and Kolling, C., Nitrogen deposition and nitrate leaching at forest edges exposed to high ammonia emissions in Southern Bavaria, Water Air Soil Pollut., 152, 233-255, 2004.

Spokes, L. J. and Jickells, T. D.: Is the atmosphere really an important source of reactive nitrogen to coastal waters?, Cont. Shelf Res., 25, 2022-2035, 2005.

Spokes, L., Jickells, T., Weston, K., Gustafsson, B. G., Johnsson, M., Liljebladh, B., Conley, D., Skjøth, C. A., Brandt, J., Carstensen, J., Christiansen, T., Frohn, L., Geernaert, G., Hertel, O., Jensen, B., Lundsgaard, C., Markager, S., Martinsen, W., Møller, B., Pedersen, B., Sauerberg, K., Sorensen, L. L., Hasager, C. C., Sempreviva, A. M., Pryor, S. C., Lund, S. W., Larsen, S., Tjernstrøm, M., Svensson, G., and Zagar, M., MEAD: An interdisciplinary study of the marine effects of atmospheric deposition in the Kattegat, Environ. Pollut., 140, 453-462, 2006.

Spranger, T., Kunze, F., Gauger, T., Nagel, D., Bleeker, A., and Draaijers, G.: Critical Loads Exceedances in Germany and their Dependence on the Scale of Input Data, Water Air Soil Pollut. Focus, 1, 335-351, 2001.

Stevens, C. J., Dise, N. B., Mountford, J. O., and Gowing, D. J.: Impact of nitrogen deposition on the species richness of grasslands, Science, 303, 1876-1879, 2004.

Stevens, C. J., Dupre, C., Dorland, E., Gaudnik, C., Gowing, D. J. G., Bleeker, A., Diekmann, M., Alard, D., Bobbink, R., Fowler, D., Corcket, E., Mountford, J. O., Vandvik, V., Aarrestad, P. A., 
Muller, S., and Dise, N. B.: Nitrogen deposition threatens species richness of grasslands across Europe, Environmental Pollution, 158, 2940-2945, 2010.

Sutton, M. A., Nemitz, E., Erisman, J. W., Beier, C., Bahl, K. B., Cellier, P., de Vries, W., Cotrufo, F., Skiba, U., Di Marco, C., Jones, S., Laville, P., Soussana, J. F., Loubet, B., Twigg, M., Famulari, D., Whitehead, J., Gallagher, M. W., Neftel, A., Flechard, C. R., Herrmann, B., Calanca, P. L., Schjoerring, J. K., Daemmgen, U., Horvath, L., Tang, Y. S., Emmett, B. A., Tietema, A., Penuelas, J., Kesik, M., Brueggemann, N., Pilegaard, K., Vesala, T., Campbell, C. L., Olesen, J. E., Dragosits, U., Theobald, M. R., Levy, P., Mobbs, D. C., Milne, R., Viovy, N., Vuichard, N., Smith, J. U., Smith, P., Bergamaschi, P., Fowler, D., and Reis, S., Challenges in quantifying biosphere-atmosphere exchange of nitrogen species, Environ. Pollut., 150, 125-139, 2007.

Sutton, M. A., Oenema, O., Erisman, J. W., Leip, A., van Grinsven, H., and Winiwarter, W.: Too much of a good thing, Nature, 472, 159-161, 2011.

Tang, S. Y. and Sutton, M. A.: A new passive sampler for longterm ambient monitoring of atmospheric ammonia, The Diffusive Monitor Newsletter, 7-9, 2003.

Theobald, M. R., Dragosits, U., Place, C. J., Smith, J. U., Sozanska, M., Brown, L., Scholefield, D., Del Prado, A., Webb, J., Whitehead, P. G., Angus, A., Hodge, I. D., Fowler, D., and Sutton, M. A., Modelling nitrogen fluxes at the landscape scale, Water, Air, \& Soil Pollution: Focus, 4, 135-142, 2004.

Theobald, M. R., Løfstrøm, P., Andersen, H. A., Pedersen, P., Walker, J., Vallejo, A., and Sutton, M. A.: An Intercomparison of Models used to Simulate the Atmospheric Dispersion and Deposition of Agricultural Ammonia Emissions in Workshop on $\mathrm{N}$ Deposition, Critical Loads and Biodiversity, 16-18th November, Edinburgh, UK, 2009.
UNECE: Manual on Methodologies and Criteria for Modelling and Mapping Critical Loads and Levels, and Air Pollution Effects, Risks and Trends, 1-254, 2004.

Van Jaarsveld, H.: The Operational Priority Substances model: Description and validation of OPS-Pro 4.1, National Institute for Public Health \& Environment, Bilthoven, The Netherlands, 1156, 2004.

Van Zanten, M. C., Sauter, F. J., Wichink Kruit, R. J., Van Jaarsveld, J. A., and van Pul, W. A. J.: Description of the DEPAC module. Dry deposition modeling with DEPAC_GCN2010, Bilthoven, the Netherlands, 1-76, 2010.

Wichink Kruit, R. J., van Pul, W. A. J., Sauter, F. J., van den Broek, M., Nemitz, E., Sutton, M. A., Krol, M., and Holtslag, A. A. M., Modeling the surface-atmosphere exchange of ammonia, Atmos. Environ., 44, 945-957, 2010.

Wichink Kruit, R. J., Schaap, M., Sauter, F. J., van Zanten, M. C., and van Pul, W. A. J.: Modeling the distribution of ammonia across Europe including bi-directional surfaceatmosphere exchange, Biogeosciences Discuss., 9, 4877-4918, doi:10.5194/bgd-9-4877-2012, 2012.

Zhang, L., Wright, L. P., and Asman, W. A. H.: Bi-directional airsurface exchange of atmospheric ammonia: A review of measurements and a development of a big-leaf model for applications in regional-scale air-quality models, J. Geophys. Res-Atmos., 115, doi:10.1029/2009JD013589, 2010. 